NBER WORKING PAPER SERIES

\title{
THE EFFECT OF MEDICAID EXPANSIONS FOR LOW-INCOME CHILDREN ON MEDICAID PARTICIPATION AND INSURANCE COVERAGE: EVIDENCE FROM THE SIPP
}

\author{
John C. Ham \\ Lara D. Shore-Sheppard \\ Working Paper 8063 \\ http://www.nber.org/papers/w8063 \\ NATIONAL BUREAU OF ECONOMIC RESEARCH \\ 1050 Massachusetts Avenue \\ Cambridge, MA 02138 \\ January 2001
}

We would like to thank Eileen Kopchik for excellent research assistance and the Joint Center for Poverty Research and the National Science Foundation (Grant No. SBR-9809546) for financial support. Part of this paper was written while Ham was a visitor in the Economics Department at the University of Pennsylvania and he thanks the department for their hospitality. We are grateful to Richard Blundell, Thomas DeLeire, Mark Duggan, Kanika Kapur, Michael Keane, Helen Levy, Bruce Meyer, Cecilia Rouse, Petra Todd, Frank Vella, Ken Wolpin, participants at the Joint Center for Poverty Research Tax and Transfer Conference, and participants in seminars at New York University, Northwestern University, Princeton University, Rutgers University, and the University of Chicago for helpful comments and suggestions. The views expressed herein are those of the authors and not necessarily those of the National Bureau of Economic Research.

(C) 2001 by John C. Ham and Lara D. Shore-Sheppard. All rights reserved. Short sections of text, not to exceed two paragraphs, may be quoted without explicit permission provided that full credit, including (C) notice, is given to the source. 
The Effect of Medicaid Expansions for Low-Income Children on Medicaid Participation and Insurance Coverage: Evidence from the SIPP.

John C. Ham and Lara D. Shore-Sheppard

NBER Working Paper No. 8063

January 2001

JEL No. I3

\begin{abstract}
$\underline{\text { ABSTRACT }}$
Increased availability of public health insurance for children has led to two potentially contradictory concerns for public policy: that expanded availability of public insurance may lead families to decline private insurance and that additional public coverage may not reach many uninsured children. We examine these two concerns using data from the 1987-1993 Surveys of Income and Program Participation. Using static models we find that the expansions resulted in increased Medicaid coverage, although the estimates of take-up are smaller than estimates from previous research. We find little evidence of a negative relationship of any significant magnitude between eligibility for Medicaid and private coverage. We also find that children who have been eligible for Medicaid longer are more likely to be enrolled in Medicaid but no more likely to have lost private coverage. Including individual fixed effects reduces the magnitude of the estimated take-up effect, while the fixed effects estimates for the private insurance regression become negative and marginally statistically significant in some specifications. Simple dynamic models of insurance choice show that insurance choice is quite persistent. The estimated long run impact of eligibility in the dynamic models is larger than the estimate from the static models, while the immediate impact of expanded Medicaid eligibility from the dynamic models is smaller than the estimated effect from the static models.
\end{abstract}

John C. Ham

Department of Economics

Ohio State University

410 Arps Hall, 1945 N. High St.

Columbus, Ohio 43210
Lara D. Shore-Sheppard

Department of Economics

Williams College

Fernald House

Williamstown, MA 01267 


\section{Introduction}

In recent years there has been a dramatic increase in public commitment to health insurance coverage for children. Beginning in the mid-1980s, a series of federal laws uncoupled Medicaid eligibility from eligibility for cash assistance (then Aid to Families with Dependent Children, or AFDC), substantially expanding the population eligible for Medicaid. Because AFDC eligibility depended partly on family structure and because the program's income threshold in most states was well below the federal poverty line, the tie to AFDC meant that previously Medicaid had covered less than half the families with incomes below the poverty line. The expansions raised the eligibility threshold from the AFDC level to at least 100 percent of the poverty line and possibly higher, depending on the age of the child. Following the federal expansions, many states expanded their Medicaid programs further to include children not covered by the federal mandates. In addition, in response to pressure from states and a continuing decline in private insurance coverage for children, in the summer of 1997 Congress and the President enacted a law creating the State Children's Health Insurance Program (CHIP) which provides states with $\$ 40$ billion over the next ten years in block grant funding (the largest increase in public spending on insurance for children in three decades) to expand further publicly-provided health insurance for children.

These expansions in public health insurance for children have led to two potentially contradictory concerns for public policy. On the one hand, policy makers have been concerned that the availability of public insurance may lead families to decline private insurance for children in favor of public coverage ("crowding out"). This may occur if the cost of public insurance for an eligible child is less for the family than the cost of employer-sponsored health 
insurance, or if employers change their dependent health insurance provisions in response to the expansions. On the other hand, recent research (Selden, Banthin, and Cohen 1998) has found that over 20 percent of all Medicaid-eligible children still do not have health insurance, with most of these children being eligible under Medicaid expansion programs. While lack of health insurance may not seem to be an important issue when children who need care can receive it in emergency room settings, research has shown that children who do not have health insurance often do not get preventive care (see for example Marquis and Long 1994, Currie and Gruber 1996, and McNeil 1995).

In this paper, we use panel data from the Survey of Income and Program Participation (SIPP), to examine how the Medicaid expansions affected insurance coverage. Specifically, we estimate static and dynamic discrete panel data models of public and private insurance participation. We first estimate static models of the effect of being eligible for Medicaid on private insurance coverage (crowding out) and the effect on public insurance enrollment (takeup) that are identical to the models estimated previously in cross-sectional data. As our results differ substantially from those of studies using the Current Population Survey, we explore various reasons for these differences.

We then utilize the panel nature of the data to extend the cross section models. Panel data in general, and the SIPP in particular, offer several advantages for studying the effect of expanded public coverage. Such data allow us to observe directly and to analyze patterns in a given child's insurance coverage over time, particularly how these patterns change following an expansion in public health insurance. We first extend the cross section models by allowing the effect of eligibility for children who are newly eligible to differ from the effect for children who 
have been eligible for a period of time, since an eligible child may not be enrolled immediately in Medicaid. Second, panel data allow us to account for unobservable individual-specific factors that may be correlated with the variables of interest in our analysis. Such factors may include the unobserved health endowment of the child, the child's parents' taste for work, or other tastes. To control for such factors we estimate models including individual fixed effects. Finally, we estimate simple dynamic models of insurance participation which allow the short-run and longrun effects of eligibility to differ. These models allow us to address the possibility that whether a person has insurance at a given time depends on that person's insurance coverage in a previous period. Thus by exploiting the panel nature of the SIPP, we are able to relax several of the assumptions commonly made in past research.

The SIPP offers several additional advantages for studying Medicaid participation, particularly tri-annual rather than annual data collection and more detailed income data. Observing variables such as income and insurance on a monthly basis allows us to correlate changes in these variables both with changes in Medicaid eligibility rules and with other timechanging variables. In addition, the detailed monthly information available in the SIPP allows us to determine eligibility with a smaller degree of error than is possible with annual data.

We find little evidence in the SIPP of a negative relationship between eligibility for Medicaid and private coverage in static models estimated using standard techniques. However we do find that children who became eligible under the expansions are more likely to be enrolled in Medicaid, a relationship that is somewhat weaker than that found in previous research. Examining the differences between the SIPP results and previous results using the CPS, we find that the difference in the private coverage results does not appear to be due to different samples, 
attrition, or the annual nature of the CPS data collection. Including fixed effects to allow for permanent unobserved characteristics of the child and family reduces the magnitude of the estimated take-up effect, while the fixed effects estimates for the private insurance regression become negative and marginally statistically significant in some specifications. However while we find that persistence is an important feature of insurance status in the SIPP, we again do not find evidence of crowding out using dynamic linear regression models. We find that the immediate impact estimates from the dynamic models are smaller than the effects estimated from the static models, but the estimates of the long run impact of eligibility from the dynamic models are somewhat larger.

\section{Background}

\section{A. Expansions in Public Health Insurance}

Medicaid is a joint state-federal program financed by state contributions and federal matching funds. ${ }^{1}$ Program participants fall into three groups: low-income aged and disabled people; the "medically needy" (people who have recently incurred large medical expenses); and low-income families with dependent children. Members of the third group were the main focus of the legislative changes, and in this paper we concentrate exclusively on them. Historically, this group was comprised of families receiving cash assistance through the AFDC program. Thus, Medicaid eligibility and participation were directly linked to the eligibility standards for

${ }^{1}$ See U.S. Committee on Ways and Means (1984-1993), Congressional Research Service (1988, 1993), Health Care Financing Administration (1988, 1990), and National Governors' Association Center for Policy Research (1988-1996) for more detailed descriptions of the Medicaid program and the expansions. 
AFDC. Generally, to qualify for AFDC a family must have had either a single parent or an unemployed primary earner. The family's income and resources also had to be less than stateestablished standards, most of which were well below the federal poverty line.

Starting in the mid-1980s, a series of federal law changes substantially diminished the link between Medicaid eligibility and AFDC eligibility by relaxing the restrictions on two-parent families and those with earned income, extending Medicaid coverage to families with incomes above the AFDC thresholds. ${ }^{2}$ Beginning with the Omnibus Budget Reconciliation Acts (OBRA) of 1986 and 1987, Congress gave states the authority to raise the income limits for Medicaid coverage of certain groups (such as infants and very young children) above the AFDC level. Congressionally mandated increases in state eligibility limits followed, most notably with the passage of OBRA 1989 and OBRA 1990. OBRA 1989 required coverage of pregnant women and children up to age 6 with family incomes up to 133 percent of the federal poverty level, and OBRA 1990 required states to cover children born after September 30, 1983 with family incomes below 100 percent of the federal poverty level. Further expansions (within certain guidelines for age and family income) were permitted at state option. In total, the expansions raised the eligibility threshold from the AFDC level to at least 100 percent of the poverty line and possibly higher, depending on age and state of residence. Age plays a role because eligibility standards for younger children were generally less restrictive, while state of residence is important because states had the option of exceeding the federal minimum eligibility limits.

\footnotetext{
${ }^{2}$ Prior to the expansions studied here, there had been minor expansions in Medicaid eligibility (such as the Ribicoff program) which allowed states (at their option) to cover children or pregnant women who met AFDC income standards but did not qualify due to family structure. The Deficit Reduction Act (DEFRA) of 1984 began the process of expanding eligibility by requiring states to cover children who lived in families that were income-eligible for AFDC, regardless of family structure.
} 


\section{B. $\quad$ Previous Literature}

There have been a number of studies examining the impact of the Medicaid expansions on insurance coverage, particularly focusing on the question of whether and to what extent the expansions caused individuals to shift from private coverage to public coverage. Most research in this area has used cross-sectional data, although a few papers have used panel data. The largest estimate of substitution between private and public insurance comes from Cutler and Gruber (1996). Using the expansions as a source of exogenous variation in eligibility, they use Current Population Survey (CPS) data from 1988 to 1993 to examine the cross-sectional relationship between eligibility for Medicaid and private coverage. They find a negative relationship between eligibility and private coverage and conclude that roughly half of the increase in Medicaid coverage due to the expansions was associated with a reduction in private insurance. Dubay and Kenney (1996) use data from the March 1989 and 1994 CPS and compare the change in private coverage for children to the change in private coverage for men, who were theoretically unaffected by the expansion of Medicaid (although in the data reported Medicaid coverage for men did rise over this period). They conclude that the increase in Medicaid eligibility led to a reduction in private coverage beyond what would have occurred in the absence of the expansions. Their estimate of the extent of substitution is that between 15 and 22 percent of total enrollment in Medicaid over this period came from private insurance (a different measure than that used by Cutler and Gruber 1996). Shore-Sheppard (1997) also uses data from the CPS, for the years 1988 to 1996 , to estimate the impact of the expansions on coverage of the newly eligible children. She finds that state-age-income cells with larger fractions of newly eligible children experienced a larger loss of private coverage. In addition, she finds that children who 
were eligible at the beginning of the period experienced a more extensive loss of private coverage than children who became eligible during the later expansions. Her estimates of the extent of substitution range from 15 to 33 percent for children for the 1988-1993 CPS (depending on the source of variation) and from 31 to 57 percent when the time period is extended to the 1996 CPS.

Three more recent studies use longitudinal data to examine insurance substitution: Blumberg, Dubay, and Norton (2000) use data from the 1990 SIPP, while Yazici and Kaestner (1998) and Thorpe and Florence (1998) use data from the National Longitudinal Survey of Youth (NLSY). Blumberg, Dubay, and Norton (2000) compare the change in insurance status for children who became eligible between the first and last interviews of the SIPP panel with the change for children who remained ineligible due to their age, controlling for characteristics of the children as of the first interview. Their estimate of the extent of substitution of public for private coverage is 23 percent for children who already had private coverage and 0 percent for children who began the panel uninsured. Although their focus is on displacement of private coverage by public coverage, in the process of examining displacement they estimate the probability that a child who is uninsured in the first interview is uninsured at the last interview. They find that this probability decreased among children whose age made them possibly affected by the expansions.

Yazici and Kaestner (1998) compare changes in public and private coverage rates between 1988 and 1992 for children who became eligible and those who did not, distinguishing between eligibility onset based on income loss and eligibility onset due to the expansions. Their estimates of the percent of Medicaid enrollment that came from private insurance range from 5 percent to 37 percent, depending on the groups of children considered; however the study design 
does not account for the possible endogeneity of selection into the comparison group. Finally, Thorpe and Florence (1998) perform a descriptive analysis and find that most children who had private insurance coverage in one year and Medicaid in the following year have parents who both lost private coverage and were unemployed in that year. Assuming that parents do not drop their own coverage when their child becomes Medicaid-eligible (an assumption contrary to the findings of Cutler and Gruber 1996), they measure crowding out as the fraction of children who move from private coverage to Medicaid but whose parents retain private coverage. Using this measure, they find that between 2 and 23 percent of previously privately insured children who enrolled in Medicaid had parents who retained private coverage, depending on the year considered and the income level of the family.

The NLSY data present a problem not encountered in the CPS or SIPP: the NLSY is composed of one particular cohort of mothers who are aging over the time period of the expansions, and thus trends in insurance coverage for children in the NLSY are different from the trends in the general population. Insurance coverage rates among children in the NLSY increased over this time period, while insurance coverage in the population of children more generally was declining. Consequently, estimated effects of the expansions from the NLSY may not be generalizable to the entire population of children. In addition, the authors of the NLSY studies restrict their samples by age, income, or insurance status. These restrictions yield quite small sample sizes from which the authors draw their conclusions. 


\section{Econometric Approach}

To examine the effects of the Medicaid expansions using the SIPP, we first consider static models of insurance coverage using a random effects framework. This framework allows us to use the same specification for the SIPP that has been used by previous researchers for the CPS. Next we exploit the fact that we have panel data to allow the effect of eligibility to differ in the first four months of eligibility and to estimate a fixed effects model. Finally, we consider simple dynamic models of insurance coverage, using both a random effects framework and a fixed effects framework.

\section{A. Cross Section Static Models}

Following the previous literature, we begin with a static model in which a family can choose whether to obtain private insurance and/or public insurance for each child. One can think of each choice having a utility associated with it (given the constraints facing the family), and the family selecting the choice with the highest utility. This will lead to a model with two index functions. The index functions in a given period $t$ can be approximated as

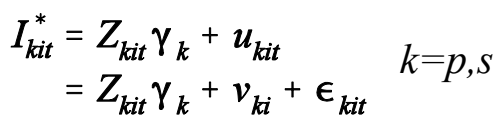

where $p$ denotes private and $s$ denotes public insurance. The vector $\mathrm{Z}_{\mathrm{kit}}$ contains various characteristics of the child and the family, including the age, sex, and race of the child, the age and education of the highest earner in the family, and the size and composition of the family. It also contains a variable ELIG ${ }_{\mathrm{it}}$, coded one if the child is eligible for Medicaid and zero otherwise, which depends on family income as well as the age of the child, the state, the month and the year. 
Year and state dummies are included in $\mathrm{Z}_{\mathrm{kit}}$ to pick up unobserved differences over time and across states such as differences in the cost of private insurance and the difficulty of the enrollment process for public insurance. Finally, $Z_{k i t}$ includes the monthly unemployment rate in the state, since this may affect the constraints facing the family. (The employment status of the head is likely to affect the family's constraints, and the unemployment rates will affect the employment status of the head.)

A child is assumed to have private insurance $\left(\mathrm{I}_{\mathrm{pit}}=1\right)$ if the index $\mathrm{I}_{\text {pit }}^{*}>0$ and to have public insurance $\left(I_{\text {sit }}=1\right.$ ) if $I_{\text {sit }}^{*}>0$. (The child has no insurance if $I_{\text {pit }}=0$ and $I_{\text {sit }}=0$.) This is essentially the model estimated by Cutler and Gruber (1996) using CPS data. Cutler and Gruber use a linear probability model and two-stage methods to estimate the equations

$$
I_{k i t}=Z_{k i t} \gamma_{k}+v_{k i}+\epsilon_{k i t}, k=p, s
$$

As they note, ELIG $\mathrm{it}_{\mathrm{it}}$ is likely to be endogenous. There are several reasons for this endogeneity: because parental wages and benefits such as health insurance are likely to be correlated (for example, low-skill household heads may both receive low wages and be less likely to be offered dependent health insurance coverage); because eligibility is a function of (potentially unobserved) individual and family characteristics that may be correlated with the demand for insurance; because a transitory shock such as a job loss affects both eligibility and coverage; and because it may proxy family income if that variable is not included as a regressor, perhaps because it too may be endogenous. However the Medicaid expansions provide a source of exogenous variation in eligibility, since children of different ages and in different states are made eligible while others remain ineligible. For example, at the end of 1991 the mandatory rules meant that a child younger than 6 years old would be eligible if his or her family income was less 
than 133 percent of the poverty line, children between ages 7 and 9 would be eligible if their family incomes were less than 100 percent of the poverty line, and older children had to have family incomes that met AFDC eligibility criteria. In addition, there were state-implemented rules that expanded the income limits further for some children. To take advantage of this variation, Cutler and Gruber create an instrument for $\mathrm{ELIG}_{\mathrm{it}}$ by drawing a random sample from the entire CPS, imputing eligibility to the sample according to the rules in each state, and calculating the fraction eligible of each state-year-age cell. This instrument, which is essentially an index of the expansiveness of Medicaid eligibility for each age group in each state and year, varies only with the legislative environment towards Medicaid for that state-year-age group and is thus uncorrelated with the error in (1), assuming that state generosity in Medicaid eligibility standards is not correlated with the availability or cost of private insurance in the state or the level of state income.

We first estimate Cutler and Gruber's model, calculating an instrument (FRACELIG ${ }_{\text {it }}$ ) analogous to theirs that varies by state, month, year and age. ${ }^{3}$ This instrument is the fraction of children of a given age (drawn randomly from the SIPP) who would be eligible in the given state, month and year. In our second specification, we replace the endogenous variable $\mathrm{ELIG}_{\mathrm{it}}$ with the exogenous variable AGEELIG $\mathrm{it}_{\mathrm{it}}$, which equals one if the child would be eligible based solely on the age criteria in the federal and state expansions effective that month and year and zero otherwise. (This variable is similar to that used by Blumberg, Dubay, and Norton 2000.) The

\footnotetext{
${ }^{3}$ While other previous research has used alternative but similar instruments (see, for example, Shore-Sheppard 1997,) the Cutler and Gruber instrument proved the most straightforward to implement in the SIPP data. We correct the standard errors to allow for correlation across time for the same individual.
} 
advantage of using AGEELIG it $_{\text {it }}$ is that we do not have to treat it as endogenous. ${ }^{4}$ However, AGEELIG $_{\text {it }}$ may overstate or understate eligibility. On the one hand, it will include children from families with incomes above the Medicaid cutoff for that state in that year. On the other hand, it will not capture children who qualify only because the family is on AFDC. We follow the literature and estimate both specifications using a linear probability model. ${ }^{5}$ (See Heckman and MaCurdy 1985 for a detailed examination of the simultaneous equations linear probability model. $)^{6}$

Given that our specifications estimated from panel data closely resemble (by design) those estimated from cross-section data, it is useful to consider the relative merits of using the SIPP compared to using multiple cross-sections for different individuals from the CPS. The major advantages of the CPS are that it is nationally representative, the sample size is large, and it does not suffer from problems peculiar to panel data such as attrition. One advantage to using panel data from the SIPP is an improvement in the imputation of a child's eligibility for Medicaid, since the SIPP provides monthly income data rather than annual data and more detailed information about the birth dates of the children. Another advantage of the SIPP relative to the CPS is in using time-changing explanatory variables. The primary explanatory variable of

\footnotetext{
${ }^{4}$ Again, we must assume that the availability or cost of private insurance (or income levels) across states and time are uncorrelated with AGEELIG $\mathrm{i}_{\mathrm{i}, \mathrm{r}}$.

${ }^{5}$ While both FRACELIG and AGEELIG may be used as instrumental variables for ELIG, for comparability with previous results we estimate the static models using only FRACELIG. We have estimated the model using both instruments and find that using the second instrument makes little differences in the results.

${ }^{6} \mathrm{We}$ also estimate the specification with AGEELIG using a probit model. The estimated marginal effects from the probit model (available upon request) differ very little from the linear probability model coefficients.
} 
interest, Medicaid eligibility status (ELIG), is one such variable. Suppose that a child is ineligible in the first half of a given year and is eligible in the second half of that year because of a Medicaid expansion on July 1 . Then in an analysis based on annual cross section data, it is not clear whether the eligibility variable should be averaged over the year or whether Medicaid status at the end of the year should be used. Finally, in the March CPS there is uncertainty about whether individuals respond to the questions about health insurance coverage in the previous year with information about their entire previous year's coverage (as the question is posed) or about their coverage at a particular point in time (as many respondents appear to do-see Swartz 1986 and Shore-Sheppard 1996 for discussions of this issue.) In addition, when the question is answered as posed, an individual who had private insurance over the entire previous year and an individual who had coverage just in a single month would be observationally equivalent in the CPS. In the SIPP we are able to match insurance coverage, eligibility, and other variables month-by-month.

\section{B. Panel Data Static Models}

The approach described above ignores two primary advantage of using panel data. First, one can allow the effect of eligibility to differ depending on how long the child has been eligible. Specifically, parents may not be immediately aware of their child's eligibility, or they may not enroll the child until the child needs medical care (for example, a child may be enrolled at a hospital emergency room while being treated for an injury or illness). If this is the case, then one would expect the effect of eligibility on insurance coverage to be smaller in the first few months of eligibility. To allow for this possibility, we redefine $Z_{\text {kit }}$ to contain two endogenous variables: a dummy variable indicating the first four months of eligibility and a dummy variable indicating 
that an individual has been eligible for five or more consecutive months. We use as instruments FRACELIG $_{\text {it }}$, FRACELIG $_{\mathrm{it}-1}, \mathrm{FRACELIG}_{\mathrm{it}-2}$, and FRACELIG $\mathrm{FR}_{\mathrm{it}-3}$.

A second advantage of panel data is that such data allow one to do a better job of controlling for differences in permanent unobserved characteristics (such as tastes or unobserved permanent health status) across individuals. With panel data it is not necessary to assume that the time-changing explanatory variables are independent of the individual-specific component of the error term if one uses a fixed effects model. For example, parents may have different tastes affecting the type of insurance available to their children, and these tastes may be correlated with unobserved factors affecting Medicaid eligibility such as income. Intuitively, with panel data we can control for these omitted taste components by comparing the same child's insurance status before and after a change in Medicaid eligibility. Thus the effect of eligibility is identified from children for whom Medicaid entitlement changes over the sample period. Further, the use of FRACELIG as an instrument and of AGEELIG as an explanatory variable in a cross section assumes that a family's location choice is uncorrelated with permanent tastes for public or private insurance, and a fixed effects model also allows us to relax this assumption. ${ }^{7}$

We should note that care needs to be taken in comparing estimates from a fixed effects model and a standard cross section model. ${ }^{8}$ The fixed effect may effectively control for the lifetime marginal utility of income, and thus by including it we would implicitly be assuming that a life-cycle model of

\footnotetext{
${ }^{7}$ Another advantage of the fixed effect specification is that it may help control for panel attrition - if an individual has a permanent propensity to leave the sample which may be correlated with characteristics such as eligibility, it will be eliminated in this specification.

${ }^{8}$ For example, Keane and Wolpin (1998) note the difference in interpretation between models of the effect of benefits on welfare participation that do, and do not, condition on state dummies. They find that this difference is important in their simulations.
} 
insurance choice is appropriate. The model without fixed effects implicitly assumes that a model of insurance participation conditional on a static (period by period) utility function and budget constraint is appropriate. If we consider an increase in the probability of being eligible for Medicaid as being equivalent to a decrease in the price of Medicaid insurance, the fixed effects estimate will capture only a positive (Frisch) substitution effect, while the cross section estimates will capture a positive (Slutsky) substitution effect as well as a positive income effect. (Here we are ignoring the fact that health insurance is not a continuous consumption good.) Thus the fixed effects approach and the cross section approach estimate different parameters and we would expect the response from the fixed effects model to be smaller (see, e.g., Browning, Deaton and Irish 1985). ${ }^{9}$

Using a linear probability model, the extension to fixed effects estimation is straightforward, and we first estimate the fixed effects model by taking deviations from the individual means in (2). As a specification check on our results, we also estimate the fixed effect model by first differencing (2) to obtain

$$
\Delta I_{k i t}=\Delta \tilde{Z}_{k i t} \gamma_{k}+\Delta \epsilon_{k i t}, \mathrm{k}=\mathrm{p}, \mathrm{s}
$$

where $\tilde{Z}_{\text {kit }}$ refers to the time-changing explanatory variables. If the two sets of fixed effects estimates differ, this would suggest that the model is misspecified; in particular, such a difference could indicate that a dynamic model may be more appropriate.

\section{Dynamic Models}

Panel data allow researchers to consider dynamic models of insurance determination. One potential drawback of (1) is that it implicitly assumes that families make a new decision

${ }^{9}$ Intuitively, think of the fixed effect controlling for lifetime income in a perfect foresight model. Then ignoring the differences in the substitution effects, the estimates conditional on the fixed effect will not have any income effect, while estimates based on a cross-section model will have a large income effect associated with them. 
each period about whether or not to obtain public or private insurance for their children, and that this decision is independent of last period's decision. Thus, it may be more appropriate to relax this assumption and consider a model of choice conditional on the lagged insurance state. For example, as noted above, insurance outcomes are closely related to job outcomes—-families often gain access to private insurance when members find a job, and can lose private insurance when they are laid off. Since there is substantial persistence in labor market histories of disadvantaged women (see, e.g., Chay and Hyslop 1998), if we do not control for labor market histories in estimation, we would expect this persistence to carry over into insurance determination. Also, (1) does not incorporate the notion of fixed costs: a family with a child on Medicaid has already paid the fixed costs of enrolling the child and is more likely to have the child on Medicaid next month.

The simplest dynamic model is obtained by adding a lagged dependent variable to (2)

$$
I_{k i t}=Z_{k i t} \gamma_{k}+\delta I_{k i t-1}+v_{k i}+\epsilon_{k i t}, \mathrm{k}=\mathrm{p}, \mathrm{s},
$$

where $\mathrm{I}_{\mathrm{pit}-1}\left(\mathrm{I}_{\mathrm{sit}-1}\right)$ equals one if the individual had private (public) insurance last period and zero otherwise. If we adopt a random effects specification for the overall error term, in the specification with ELIG, we must consider both ELIG and the lagged dependent variable as endogenous (see, e.g., Hsiao 1986). In this case we can use FRACELIG $\mathrm{it}_{\mathrm{it}}, \mathrm{FRACELIG}_{\mathrm{it}-1}$, AGEELIG $_{\mathrm{it}}$, AGEELIG $_{\mathrm{it}-1}$ and lags of the other explanatory variables as instruments. For the case where AGEELIG ${ }_{i t}$ enters equation (4) instead of ELIG ${ }_{\mathrm{it}}$, we can use FRACELIG ${ }_{\mathrm{it}}, \mathrm{FRACELIG}_{\mathrm{it}-1}$, AGEELIG $_{\mathrm{it}-1}$ and lags of the other explanatory variables as instruments. Dynamic models allow the effect of changes in Medicaid eligibility to increase over time, as opposed to assuming that the entire effect occurs immediately. One can also estimate the long-run effect of eligibility by 
dividing its coefficient by one minus the coefficient on the lagged dependent variable.

If we assume a fixed effect specification for the error in (4), we cannot simply use least squares (Nickell 1981). Instead, the easiest way to proceed is to first-difference (4) and obtain

$$
\Delta I_{k i t}=\Delta \tilde{Z}_{k i t} \gamma_{k}+\delta\left(I_{k i t-1}-I_{k i t-2}\right)+\left(\epsilon_{k i t}-\epsilon_{k i t-1}\right), \mathrm{k}=\mathrm{p}, \mathrm{s} .
$$

Even if we assume that $\epsilon_{\mathrm{kit}}$ is white noise (i.e., no autocorrelation conditional on the fixed effect), we must treat $\left(\mathrm{I}_{\mathrm{kit}-1}-\mathrm{I}_{\mathrm{kit}-2}\right)$ as endogenous given the correlation between $\mathrm{I}_{\text {kit-1 }}$ and $\epsilon_{\text {kit-1 }}$ (Hsiao 1986, Arellano and Bond 1991). If we use $\Delta \mathrm{ELIG}_{\mathrm{it}}$ as an explanatory variable in (5), we must also treat it as endogenous. Assuming that $\epsilon_{\mathrm{kit}}$ is indeed white noise, we can use lagged values of the dependent value from period $\mathrm{t}-2$ and earlier as instruments. If we do not assume that $\epsilon_{\mathrm{kit}}$ is white noise, we again use FRACELIG ${ }_{\mathrm{it}}, \mathrm{FRACELIG}_{\mathrm{it}-1}, \mathrm{AGEELIG}_{\mathrm{it}}, \mathrm{AGEELIG}_{\mathrm{it}-1}$ and lags of the other explanatory variables as instruments. The case where we use $\Delta$ AGEELIG $_{\mathrm{it}}$ as an explanatory variable in (5) instead of $\Delta \mathrm{ELIG}_{\mathrm{it}}$ proceeds in a similar fashion.

\section{Data}

As noted previously, the data used in the empirical analysis are from the Survey of Income and Program Participation (SIPP), a series of longitudinal data sets collected for a random sample of the U.S. population by the Census Bureau. The SIPP is collected in a series of panels, each one containing approximately 17,000 households, on average. For ease of interviewing, the entire sample is randomly split into four rotation groups, and one rotation group is interviewed each month. Each rotation group in a SIPP panel is interviewed once every four months about employment and program participation during the previous four months (termed a wave). Each SIPP panel lasts approximately 32 months, although the length of the panel varies, 
from 24 months for the 1988 panel to 40 months for the 1992 and 1993 panels. A new panel is introduced each year, which yields more than one panel with data covering a particular point in time. We use the 1987, 1988, 1990, 1991, 1992, and 1993 panels, which cover the period from October 1986 to August 1995 (the 1989 panel is not used because it was ended after only three waves).

Our analysis sample is composed of children in original sample households (that is, households interviewed in the first wave) who are younger than 16 years old at the first time they are observed and live in states that are identified in the SIPP (40 states and the District of Columbia are identified — the others are grouped for confidentiality). We drop children who are observed only once $(<1$ percent of the sample), have breaks in their data (children who leave the sample and then return $-<3$ percent of the sample) and children who move between states during the sample period (approximately 4 percent of the sample). ${ }^{10}$ To address the possibility that our results may be driven by spurious transitions (for example when a child is erroneously coded as having public insurance in a given period although in fact he does not have public insurance in that period nor in the preceding or following periods), we recode the data to eliminate any spells of one month duration. Comparing the estimated coefficients in the linear probability models using this smoothed data to results using the original data, we find that with the exception of the coefficients on the lagged dependent variables, the coefficients are well within the confidence

\footnotetext{
${ }^{10}$ Children with breaks in their data are dropped because their insurance status while out of the sample is unknown, and this creates difficulties in the dynamic models. We drop children who move between states during the sample because the relatively small number of such children made estimating fixed effects models with state dummies included difficult. Results from models without fixed effects including these children in the sample are essentially the same as the results when these children are not included, however.
} 
intervals. Unsurprisingly, the coefficients on the lagged dependent variables are higher in the smoothed data. We report the coefficients from the smoothed data regressions below.

Another measurement issue in the SIPP is that of "seam bias." Census Bureau researchers have shown that there are a disproportionate number of transitions in the fourth (interview) month (see, e.g., Young 1989, Marquis and Moore 1990). The approach to this problem that has been used in the past is to use index functions or transition rates that apply to the four month period covered by the interview. However, this approach has the disadvantage that the information on the timing of transitions that reportedly occurred in months other than the seam month is lost. To test the importance of this seam bias problem for our results, we estimate the models two different ways: using all of the monthly data and using only the fourth month of each wave (dropping the first three months). The results are overall quite similar, and there is no consistent pattern in the differences between coefficients. It is not the case that one specification produces consistently larger or smaller coefficients, for example. For completeness we report results from the four-month specification in the Appendix, but they are discussed only in the cases when they differ substantially from the monthly data results.

Finally, due to the number of person-months in the sample, it proved computationally infeasible to estimate our models on the entire sample of $1,930,740$ person-months. Consequently, we draw a 50 percent random sample of individuals and use all months for individuals in that sample in our regressions. ${ }^{11}$

In Table 1 we present the sample means for the variables used in our regressions. The

\footnotetext{
${ }^{11}$ In future drafts we will estimate the model from each $50 \%$ sample and then obtain overall estimates by combining the estimates from the two samples using minimum distance.
} 
insurance variables are private insurance and Medicaid, where we define private coverage to include CHAMPUS coverage. A child may report both private and public coverage, although this is relatively uncommon (only 1.8 percent of the total months). As noted above, we use two alternative eligibility variables - a variable coded one if the child is imputed to be eligible in the month according to age, family income, and the rules in effect that month (ELIG), and a variable coded one if an expansion affecting that age child had been passed (AGEELIG). As has been shown previously in CPS data, both eligibility and Medicaid coverage rise across the period, while private coverage falls. The age-eligible variable starts the sample period below the imputed eligibility variable ( 2.3 percent of months in the 1987 SIPP have AGEELIG=1 while 19.6 percent have ELIG=1) but rises quickly, and by the end of the sample period over threequarters of months have AGEELIG=1. Characteristics of the child and the family are also included in the regressions. As we are examining health insurance, we use the "health insurance

unit" as the family definition. This is the family unit relevant for health insurance purposes - that is, the head, spouse, and any minor children (or older children who are full-time students).

\section{Results}

\section{A. Static Model}

Table 2 presents results from the static model of equation (2) for public and private insurance. The first two columns in each panel show results without including state effects and with state effects, while the third column gives the estimates from the exact specification used by Cutler and Gruber (1996) in CPS data. In all columns the state-year-month-age eligibility index FRACELIG is used as the instrument for eligibility. 
Looking first at the Medicaid participation equation, the coefficients on the individual and family demographic variables enter as expected and appear to be relatively stable across specifications. Children who are white, have older parents, parents with more education, two parents or only a male head (relative to being in a female-headed family), smaller families, or who have at least one earner in their family, are significantly less likely to be enrolled in Medicaid. Addition of state dummies affects primarily the coefficients on no earner and only a male head, increasing both in absolute value. The state unemployment rate is positive and significant until the state dummies are added, when it becomes insignificant.

The eligibility variable, which is positive and significant in all specifications, as expected, is also strongly affected by the addition of state indicators, with the magnitude of the coefficient falling from 0.196 to 0.120 . This latter estimate implies that a ten-percentage point increase in eligibility results in a 1.2 percentage-point increase in Medicaid coverage. The coefficient changes little when the exact CPS specification is used. It is interesting to note that this estimate is smaller than the corresponding coefficient in the 1988-1993 CPS data, which is 0.235 (Cutler and Gruber 1996, p. 408) or the coefficient in the 1988-1996 CPS data, which is 0.197 (ShoreSheppard 1997). We explore possible reasons for this difference below.

The private insurance equation results are presented in the right-hand panel of Table 2 . Again the demographic and family variables have the signs expected — generally the opposite of the signs in the Medicaid regression with the exception of the variables for the number of earners in the family, which indicate that the more earners a family has, the more likely the children are to have private coverage. The sign of the coefficient on eligible is positive and (when state dummies are included) statistically insignificant. Again this is unlike the results from the CPS, 
which showed a significantly negative relationship between eligibility and private coverage (-0.074 in 1988-1993 (Cutler and Gruber 1996) or -0.091 in 1988-1996 (Shore-Sheppard 1997)). ${ }^{12}$

\section{B. Exploration of the Differences Between CPS and SIPP Results}

There are several possible reasons why the CPS and SIPP results differ. First, the CPS identifies all states while the SIPP does not identify the smallest states and consequently they are dropped from our sample. To check the importance of this explanation, we estimated the model using the CPS data and omitting states and ages not represented in the SIPP sample. This yielded estimates of the coefficient on eligibility for the Medicaid equation of $0.136(0.013)$ and for the private equation of $-0.070(0.016)$ (corresponding to columns (3) and (6) of Table 2, respectively). The Medicaid coefficient is thus quite close in the CPS and SIPP when equivalent samples are compared, while the private coefficient remains very different.

Another possible reason for the remaining difference is the composition of the SIPP sample: if through attrition the SIPP sample has become selected in some way, the results may not be comparable to the CPS results. We explore this issue by running the models using only data from the first year of each panel, since such data should suffer less from attrition. We find that the estimates of the effect of eligibility are similar although somewhat smaller in absolute value than when the whole sample is used, indicating that the difference does not appear to be due to attrition in the SIPP.

${ }^{12}$ The results using one observation per wave (presented in Appendix Table A1) are similar to the results in Table 2, although they are somewhat closer to the CPS results-the coefficient on eligibility is slightly larger in the Medicaid equation and negative (although insignificantly different from zero) in the private insurance equation. The differences are not significant, however. 
A third possible explanation for the CPS-SIPP discrepancy is that it arises from the different methods of data collection in the CPS and SIPP. One primary difference between the CPS and SIPP is the reference period of each survey: annual for the CPS, and monthly for the SIPP. In order to explore the impact of the reference period on the estimates, we create a CPS "look-alike" from the SIPP data. That is, we use the monthly data in SIPP to create an annual observation for each child. There are several issues which arise when creating this look-alike sample. First, attrition is likely to be more severe in a longitudinal survey such as the SIPP. Second, as noted above, it is not clear how the CPS respondents answer the insurance questions (Swartz 1986, Shore-Sheppard 1996). To address these issues, we create annual data from the SIPP using several alternative hypotheses about the sample to use and the way respondents might answer the CPS. We try three alternative samples of SIPP data: children who have 12 months of data from the first full year of the panel; children who have 12 months of data early in the panel (although not necessarily from the first full year); and children who have at least 6 months of data from the first year of the panel. We combine these three samples with five possible assumptions about how respondents might answer an annual (CPS) insurance question: as posed (had insurance at any time in the previous year); at a point in time (had insurance the last month of the year); over a shorter reference period (had insurance at any time in the last 3 months or alternatively the last 6 months); and for the majority of the year (had insurance over half of the time). For each of the three samples, variables other than the insurance status are summed over the months in the SIPP to create annual data. In particular, to create eligibility, family income is added over all of the months and eligibility is imputed using the annual data. Characteristics such as family size are obtained from the last month of each sample (corresponding to the use of 
March data on such variables in the CPS.)

Health insurance coverage rates in the CPS and SIPP look-alike data match most closely when the sample used is children who had at least 6 months of data. Mean coverage rates for the CPS and for this sample under the various assumptions are given in Table 3. For Medicaid, the CPS coverage rates appear to match most closely the rates under the hypothesis that respondents are answering the question as posed. For private coverage, however, the CPS appears to be eliciting a lower level of coverage, with the rates matching most closely the rates arising from the hypotheses that respondents are answering as of the last 3 months or the last 6 months.

The results from regressions using the look-alike samples are presented in Table 4. For each sample, there are four specifications, corresponding to columns (2), (3), (5), and (6) of Table 2. The entries show the coefficients on eligibility from the various assumptions. Comparing the coefficients from the SIPP results in Table 4 to those in Table 2 and to the CPS results (in the top row of Table 4), it appears that annualizing the SIPP data gives results that are somewhat closer to the CPS results (larger coefficients on Medicaid, and smaller coefficients on private coverage). Notably, however, the coefficients on private coverage remain smaller than in the CPS results, and are not statistically different from zero. We conclude from this exercise that the annual nature of the CPS data collection is not the only source of differences in the results; the SIPP consistently provides lower (and statistically insignificant) estimates of the magnitude of private coverage loss than does the CPS.

C. Alternative Specifications of the Static Model

As discussed above, an alternative specification of the eligibility effect is to use AGEELIG, a variable that is based solely on the eligibility expansions in place for that state- 
month-age cell and that is therefore plausibly exogenous. In Table 5 we show estimates of equation (1) using this variable. The table is divided into two panels, with the left panel showing estimates using the 50 percent sample and the right panel showing estimates using a sample of children from families with incomes less than 200 percent of the federal poverty line at the first month. Since AGEELIG equals one for many children who will never qualify for Medicaid due to their family income, using this variable may understate the true effect of the expansions on the targeted population. Consequently we examine the effect of this variable in a population with a higher probability of actually qualifying for Medicaid..$^{13}$

The effects of AGEELIG on Medicaid enrollment in the 50 percent sample are consistent with the effects found for imputed eligibility—being age-eligible for Medicaid increases the likelihood a child is enrolled in Medicaid. While statistically different from zero, the estimated effects are much smaller, however, as would be expected given the inclusion of children who are age-eligible but unlikely to be actually eligible. For private insurance, there appears to be no relationship between expansion eligibility and having private coverage.

The results in the poor sample are similar to those in the 50 percent sample, although consistent with the interpretation that the effect of age-eligibility will be understated in the 50 percent sample, the coefficients on AGEELIG in the Medicaid equations are somewhat larger in the poor sample. They are still not as large as the coefficients on actual eligibility in Table 2, however. The private regression results are essentially the same as in the 50 percent sample, and again there is no evidence of a negative relationship between eligibility and private coverage.

${ }^{13}$ This strategy is similar to that of Blumberg, Dubay and Norton (2000) who use an eligibility variable that only depends on age and a sample consisting only of poor and near-poor children in their examination of data from the first and last panels of the 1990 SIPP. 
Finally, although the eligibility variable is different, the individual and family explanatory variables have quite similar coefficients in the eligibility and AGEELIG equations. ${ }^{14}$

\section{Allowing for Different Effects of Eligibility Over Time}

In the models above, we have implicitly assumed that the effect of eligibility is constant over time. However the use of panel data permits us to relax this assumption and allow the effect of eligibility to differ between children who are newly eligible and children who have been eligible for several months. If parents do not immediately enroll their children when the children become eligible, then the effect of eligibility may differ depending on how long the child has been eligible. We split eligibility into eligibility in the first four months and eligibility for five months or more to test whether this may in fact be the case. The results of this specification are presented in Table $6{ }^{15}$ From these results it is clear that children are not always immediately enrolled upon becoming eligible, lending support to the concern that parents are either not aware of their child's eligibility or are aware but do not enroll their child until urgent care is needed. Indeed, in the Medicaid regression the coefficient on the first four months of eligibility is actually negative, while the coefficient on eligibility after five or more months is positive and larger in magnitude than the effect of eligibility in Table 2. The coefficient indicates only a 1.6 percentage-point increase in coverage with a 10 percentage-point increase in eligibility, however, so that even among children who have been eligible for several months the enrollment rate is still relatively low. In the private regression, the two effects are similar in magnitude (both are

\footnotetext{
${ }^{14}$ The corresponding results from the 4-month observations (Appendix Table A2) are similar to the results in Table 5 .

${ }^{15}$ We did not use this specification earlier in order to keep our specification as comparable as possible to that of earlier work.
} 
insignificantly positive in the regression with state effects), and it is not possible to reject that the effects are equal. (In both the Medicaid and private regressions the effects of the other covariates are essentially unchanged by allowing the effect of eligibility to vary over time.) Thus children appear to be more likely to be enrolled in Medicaid, but no more likely to have lost private coverage, after having spent some time eligible for Medicaid. ${ }^{16}$

\section{E. $\quad$ Models Including Individual Fixed Effects}

Models including fixed effects are presented in Table $7 .{ }^{17}$ These models relax the assumption that the individual component of the error term is uncorrelated with the explanatory variables. Each model is run using differences from individual means to eliminate the fixed effect, and then re-run in first-differences as a specification check. The coefficients from both types of fixed effects models appear to be smaller in absolute value than the coefficients from the simple static models. In particular, the coefficient on eligibility in the Medicaid equation is reduced to 0.040 ( 0.013 in the first-differenced model) from 0.120 , and the coefficient on ageeligibility is reduced to 0.007 (0.002 in the first-differenced model) from 0.017 . Including individual fixed effects in the private insurance equation also reduces the magnitude of virtually all of the estimated coefficients, and changes the sign of some. The coefficient on eligibility is now negative (as would be the case in the presence of crowding out), although it is statistically significant only when age-eligibility is used in the differences from individual means

\footnotetext{
${ }^{16}$ The results using 4-month observations (Appendix Table A3) are similar to the results in Table 6, although the first wave eligibility effects are smaller in the Medicaid regressions and larger in the private regressions. In addition, in the private regressions we can now reject that the effects for the first wave of eligibility are the same as those for longer periods of eligibility.

${ }^{17}$ For simplicity in this and the following specifications, we return to using a single-variable parameterization of eligibility.
} 
specification.

There are two possible explanations for the reduction in the estimated coefficients when fixed effects are used. First, as discussed above, the cross-sectional and fixed effects models may be estimating different parameters, with the fixed effects models estimating a substitution effect rather than a combined substitution and income effect. Second, the smaller size of the eligibility coefficient may indicate that once the between-child variation in eligibility is removed, the probability of taking up coverage among the newly eligible is smaller. This would be the case if the propensity to take up public coverage differs across children. As the eligibility effects are identified from children who become eligible over the course of the sample (and consequently are likely to be further up the income distribution and have greater access to private coverage), this explanation for the smaller coefficients when fixed effects are included is plausible. ${ }^{18}$

Although the coefficients are similar in sign in the two types of fixed effects specifications, they do differ, with the estimated coefficients from the difference from individual means specification generally being larger. This suggests that a model that takes account of dynamics in insurance coverage may be more appropriate.

\section{F. Simple Dynamic Models}

In this section we relax the assumption that insurance choice in the current period is independent of last period's choice by estimating simple dynamic models. The results are presented in Table 8 (using the endogenous eligibility variable) and in Table 9 (using the exogenous age-

${ }^{18}$ Again the results from the four-month data are similar, although the eligibility coefficients are generally larger in the Medicaid regressions, and more negative in the private regressions (both eligibility coefficients using differences from individual means are significantly different from zero). The coefficients on family structure are also generally larger. 
eligibility variable). In each table we present three specifications for the two insurance types. The first specification in columns (1) and (4) is a levels specification, which assumes that the individual component of the error is uncorrelated with the explanatory variables $\tilde{Z}_{k i t}$. Since the lagged dependent variable is likely to be correlated with the error term (i.e., we would expect to find autocorrelation when not controlling for person-specific factors through a fixed effect), we include FRACELIG, AGEELIG, and lags of those variables and the family characteristics in the first stage regression for the lagged dependent variable but exclude these variables from the second stage equation. The second specification in columns (2) and (5) relaxes the assumption of uncorrelated individual effects, but assumes that there is no serial correlation in the transitory component error term, (i.e., errors for the same individual are correlated over time only because of the person-specific effect). This assumption allows us to use further lags of the dependent variable as additional instruments in the first stage equation. The final specification in columns (3) and (6) allows for the possibility of serial correlation in the transitory component of the error term. In this case the lags of the dependent variable are no longer valid instruments, and we include the same explanatory variables in the first stage equation as in columns (1) and (4). The corresponding estimates for the data based on the 4 month observations are given in Appendix Table A5. Here we will discuss both sets of estimates as there are substantial differences between the parameter estimates in Table 8 and Table A5.

As a summary statistic we first estimate an autoregressive model with no explanatory variables. Not surprisingly, there is a very high degree of persistence in the data-the coefficients (standard errors) on lagged coverage in the monthly data are $0.951(0.001)$ and $0.959(0.0004)$ in the Medicaid and private regresssions, respectively. In the four-month data the autoregressive coefficients for the same equations are estimated as $0.814(0.002)$ and $0.830(0.001)$, respectively. 
As noted above, columns (1) and (4) add regressors to the simple specification and treat the lagged dependent variable as endogenous. As one might expect, the lagged dependent variable has substantial and significant coefficients in both insurance equations, even when covariates are included. The immediate impact of Medicaid eligibility in the public insurance equation is estimated to be 0.013 , and the estimated long run effect is thus $0.013 /(1-0.948)=0.25$, which is substantially larger than the estimate in column (2) of Table 2. The impact and long run effects of eligibility in the private insurance equation are 0.024 and 0.072 , with the long run effect being substantially larger than the estimate in column (5) of Table 2. The long run effects from columns (1) and (4) of Table A5 (based on the four-month data) are 0.235 in the public insurance equation and 0.056 in the private insurance equation, which are quite close to the estimates from the monthly data. These results indicate that eligibility for Medicaid may have a cumulative effect, with relatively low takeup rates in the short run, but higher take-up in the long run.

The results in columns (2) and (5) of Tables 8 and A5, which allow for fixed effects and include lagged dependent variables while assuming the transitory error is serially uncorrelated, are relatively unstable and implausible. First, the coefficients on the lagged dependent variable are much smaller in the four-month data. Second, the long run eligibility effects differ widely between the monthly and four-month data. The long run effects for public insurance are 0.090 and 0.115 in the monthly and four-month data respectively, while the long run eligibility effects in the private insurance equation are 0.857 and -0.071 . Further doubt concerning the estimates in columns (2) and (5) in each Table is generated by comparing them with columns (3) and (6) of each Table. If the lags of the dependent variable are valid instrumental variables, the results in columns (3) and (6) should be similar to those in columns (2) and (5), but should be less precise. While we have not carried out a formal Hausman test, it is clear that this is not the case in Tables 8 and A5, with the differences for 
the private insurance equation estimated from monthly data being the most pronounced. Considering the public insurance equation in column (3) first, the long run effect of Medicaid eligibility is 0.048 in the monthly data and 0.094 in the four-month data. For the private insurance results shown in column (6), the long run eligibility effects are -0.0024 and -0.044 in the monthly data and the fourmonth data respectively. Thus it appears that the assumption of serially uncorrelated errors is unlikely to hold in the data. If we discard the estimates in columns (2) and (5) of Tables 8 and A5 as being rejected by the data, the dynamic models produce a range of estimates similar to the range produced by the static models. In particular, the long run estimates from the dynamic specification in levels are similar to, though larger than, the estimates from the static levels models, while the dynamic specification including fixed effects produces estimates that are similar to the static fixed effects estimates but again are somewhat larger in magnitude.

Table 9 and Appendix Table A6 contain the dynamic specifications for the case where AGEELIG is used as the measure of Medicaid eligibility. The results are quite similar to those in Tables 8 and A5, except that the coefficient on eligibility is no longer implausibly large when first differences are used and the lagged dependent variables are assumed to be valid instrumental variables. There is a similar relationship to that described above between the dynamic and static results using AGEELIG, with the long run results from the dynamic model in levels being generally larger than the results from the static model, and similarly with the fixed effects. While most of the long run results from the dynamic models are broadly in agreement with the static results, the differences between the long run and impact results show that the underlying dynamics of insurance choice are an important part of an examination of the behavioral effects of the Medicaid expansions. As we have only begun to explore the dynamics of insurance choice in this paper, this topic is an important one for future work. 


\section{Conclusions}

In this paper we use data from the SIPP and static and dynamic discrete panel data models to examine the impact of expansions in Medicaid eligibility on public and private insurance coverage. Our results indicate that the expansions resulted in increased Medicaid coverage, but unlike previous research, we find little evidence of a statistically significant negative relationship between eligibility for Medicaid and private coverage. Further, not only are the estimates of the impact on private coverage generally insignificant, but the SIPP estimates are also consistently smaller than the estimates from the CPS. The SIPP also produces a somewhat lower estimate of public insurance take-up than does the CPS. Our estimates do not change qualitatively when the SIPP data are annualized to resemble the CPS. Consequently it does not appear that the differences in the CPS and SIPP results are due solely to the annual nature of the CPS data collection.

We use the panel nature of the SIPP to relax several econometric constraints in the static specification of insurance coverage used in the CPS. Allowing the effects of eligibility to differ for children who have just become eligible and children who have been eligible for several months, we find that children appear to be more likely to be enrolled in Medicaid but no more likely to have lost private coverage after having spent some time eligible. Including a fixed effect to allow for permanent unobserved characteristics of the child and family reduces the magnitude of the estimated take-up effect, while the fixed effects estimates for the private insurance regression become negative and marginally statistically significant in some specifications. Finally, we examine simple dynamic models of insurance choice, relaxing the assumption that insurance choice in each period is independent of the previous period's choices. 
We find that insurance choice is quite persistent. When dynamics are accounted for, the estimated long run impact of eligibility is somewhat larger than the (constant) effect estimated from static models, while the immediate impact of expanded Medicaid eligibility in the dynamic models is smaller than the static estimate. Thus both the dynamic specification and the specification allowing the effect of eligibility to differ with time indicate that in determining the impact of the expansions, it is important to account for the fact that some children may not enroll immediately. From a policy perspective, these results indicate that a strategy to increase the takeup of Medicaid among eligible children would be to inform parents about the possibility that their child is eligible and/or to inform parents of the benefits of enrolling their child in Medicaid. Such information may help reduce the apparent gap between eligibility onset and enrollment.

In this research we have used panel data to relax several implicit assumptions made in static models and begun to explore the dynamics of insurance choice in the presence of public insurance unrelated to cash assistance. However more research is necessary for a full understanding of the underlying dynamic processes. For example, in future work we will explore transitions between insurance states in more detail, examining when children move between the states of private insurance, public insurance, and no insurance, and how those transitions are related both to the expansion of public coverage and to employment changes in the child's family. Using the SIPP we can address questions such as whether the expansions changed the length of time children spend uninsured and how events such as job loss of the family head affect insurance coverage. However it is important to recognize that while the SIPP is a rich source of information on employment and insurance coverage over time, there are several questions we are unable to answer using the SIPP. In particular, the SIPP does not provide information on 
whether parents are offered health insurance for themselves or their dependents or any information on the parameters of the insurance coverage they have (such as premiums or copayments). Finally, while there is information on health status of adults in the SIPP, such information is very limited for the children in the data. Consequently, it is unlikely that questions involving the effects of such factors on insurance dynamics can be answered for the period of the Medicaid expansions. 


\section{References}

Arellano, M. and S. Bond. 1991. "Some Test of Specification for Panel Data: Monte Carlo Evidence and an Application to Employment Equations." Review of Economic Studies 58(2): 277-297.

Blumberg, L. J., L. Dubay, and S. A. Norton. 2000. "Did the Medicaid Expansions for Children Displace Private Insurance? An Analysis Using the SIPP." Journal of Health Economics 19(1): 33-60.

Browning, M., A. Deaton and M. Irish 1985. "A Profitable Approach to Labor Supply and Commodity Demands over the Life-Cycle.” Econometrica 59(4): 503-543.

Chay, K. Y. and D. Hyslop. 1998. "Identification and Estimation of Dynamic Binary Response Panel Data Models: Empirical Evidence using Alternative Approaches." Center for Labor Economics, UC Berkeley, Working Paper No. 5.

Currie, J. and Gruber, J. 1996. "Health Insurance Eligibility, Utilization of Medical Care, and Child Health." Quarterly Journal of Economics 111(2), 431-466.

Cutler, D. M. and J. Gruber. 1996. "Does Public Insurance Crowd Out Private Insurance?" Quarterly Journal of Economics 111(2): 391-430.

Dubay, L. C. and G. Kenney. 1996. "The Effects of Medicaid Expansions on Insurance Coverage of Children." The Future of Children 6(1): 152-161. and _ 1997. "Did the Medicaid Expansions for Pregnant Women Crowd Out Private Insurance?" Health Affairs 16(1).

Heckman, J. J. 1981. "The Incidental Parameters Problem and the Problem of Initial Conditions in Estimating a Discrete Time-Discrete Data Stochastic Process." In C. Manski and D. McFadden (eds)., Structural Analysis of Discrete Data. Cambridge, MA: MIT Press. and T. E. MaCurdy. 1985. "A Simultaneous Equations Linear Probability Model." Canadian Journal of Economics 18(1): 28-37.

Hsiao, Cheng. 1986. Analysis of Panel Data Cambridge, UK: Cambridge University Press. Hyslop, D. R. 1999. "State Dependence, Serial Correlation, and Heterogeneity in Intertemporal Labor Force Participation of Married Women." Econometrica 67(7): 1255-1294.

Keane, M. and K. Wolpin. 1998. "Estimating Welfare Effects Consistent with Forward Looking Behavior." Mimeo, Department of Economics, University of Pennsylvania.

Marquis, K. H. and J. C. Moore. 1990. "Measurement Errors in the Survey of Income and Program Participation (SIPP) Program Reports." 1990 Annual Research Conference Proceedings, Washington, D.C.: U.S. Bureau of the Census.

Marquis, M. S. and Long, S. H. 1994. "The Uninsured Access Gap: Narrowing the Estimates." Inquiry 31(4), 405-414. 
McNeil, J. M. 1995. "The Effect of Health Insurance Coverage on Doctor and Hospital Visits: 1990 to 1992." Household Economic Studies, Current Population Reports, P70-44.

Nickell, S. 1981. "Biases in Dynamic Models with Fixed Effects." Econometrica 49(6): 14171426.

Selden, T. M., J. S. Banthin, and J. W. Cohen. 1998. "Medicaid's Problem Children: Eligible but not Enrolled." Health Affairs 17(3): 192-200.

Shore-Sheppard, L. D. 1996. "Medicaid and Health Insurance for Children: Essays in Empirical Economics." Unpublished Ph.D. Dissertation. Princeton University. . 1997. "Stemming the Tide? The Effect of Expanding Medicaid Eligibility on Health Insurance Coverage." University of Pittsburgh Working Paper (November).

Swartz, K. 1986. "Interpreting the Estimates from Four National Surveys of the Number of People Without Health Insurance." Journal of Economic and Social Measurement 14.

Thorpe, K. E. and C. S. Florence. 1998. "Health Insurance Among Children: The Role of Expanded Medicaid Coverage." Inquiry 35:369-379.

Yazici, E. and R. Kaestner. 1998. "Medicaid Expansions and the Crowding Out of Private Health Insurance." National Bureau of Economic Research Working Paper 6527 (April).

Young, N. 1989. "Wave Seam Effects in the SIPP: Implications for Analysis." Mimeo, U.S. Bureau of the Census. 
Table 1: Summary Statistics of Variables Used in Regressions

\begin{tabular}{|c|c|c|c|c|c|c|}
\hline SIPP Panel: & 1987 & 1988 & 1990 & 1991 & 1992 & 1993 \\
\hline \multicolumn{7}{|l|}{ Insurance Variables: } \\
\hline Medicaid & $\begin{array}{c}0.110 \\
(0.001)\end{array}$ & $\begin{array}{l}0.108 \\
(0.001)\end{array}$ & $\begin{array}{c}0.153 \\
(0.001)\end{array}$ & $\begin{array}{c}0.158 \\
(0.001)\end{array}$ & $\begin{array}{c}0.171 \\
(0.001)\end{array}$ & $\begin{array}{c}0.180 \\
(0.001)\end{array}$ \\
\hline Private insurance & $\begin{array}{c}0.726 \\
(0.001)\end{array}$ & $\begin{array}{c}0.722 \\
(0.001)\end{array}$ & $\begin{array}{c}0.685 \\
(0.001)\end{array}$ & $\begin{array}{c}0.711 \\
(0.001)\end{array}$ & $\begin{array}{c}0.697 \\
(0.001)\end{array}$ & $\begin{array}{c}0.674 \\
(0.001)\end{array}$ \\
\hline \multicolumn{7}{|l|}{ Eligibility variables: } \\
\hline Imputed eligible & $\begin{array}{c}0.196 \\
(0.001)\end{array}$ & $\begin{array}{c}0.202 \\
(0.001)\end{array}$ & $\begin{array}{c}0.292 \\
(0.001)\end{array}$ & $\begin{array}{c}0.302 \\
(0.001)\end{array}$ & $\begin{array}{c}0.325 \\
(0.001)\end{array}$ & $\begin{array}{c}0.356 \\
(0.001)\end{array}$ \\
\hline $\begin{array}{l}\text { Age-eligible ( }=1 \text { if } \\
\text { expansion for child's age) }\end{array}$ & $\begin{array}{c}0.023 \\
(0.000)\end{array}$ & $\begin{array}{c}0.070 \\
(0.001)\end{array}$ & $\begin{array}{l}0.375 \\
(0.001)\end{array}$ & $\begin{array}{c}0.507 \\
(0.001)\end{array}$ & $\begin{array}{c}0.652 \\
(0.001)\end{array}$ & $\begin{array}{c}0.784 \\
(0.001)\end{array}$ \\
\hline \multicolumn{7}{|l|}{ Demographic variables: } \\
\hline Male & $\begin{array}{c}0.515 \\
(0.001)\end{array}$ & $\begin{array}{c}0.508 \\
(0.001)\end{array}$ & $\begin{array}{c}0.511 \\
(0.001)\end{array}$ & $\begin{array}{c}0.512 \\
(0.001)\end{array}$ & $\begin{array}{c}0.520 \\
(0.001)\end{array}$ & $\begin{array}{c}0.515 \\
(0.001)\end{array}$ \\
\hline White & $\begin{array}{l}0.825 \\
(0.001)\end{array}$ & $\begin{array}{c}0.823 \\
(0.001)\end{array}$ & $\begin{array}{c}0.776 \\
(0.001)\end{array}$ & $\begin{array}{c}0.813 \\
(0.001)\end{array}$ & $\begin{array}{l}0.805 \\
(0.001)\end{array}$ & $\begin{array}{c}0.808 \\
(0.001)\end{array}$ \\
\hline Age & $\begin{array}{l}8.315 \\
(0.011)\end{array}$ & $\begin{array}{c}8.272 \\
(0.012)\end{array}$ & $\begin{array}{c}8.331 \\
(0.008\end{array}$ & $\begin{array}{c}8.347 \\
(0.010)\end{array}$ & $\begin{array}{l}8.328 \\
(0.007)\end{array}$ & $\begin{array}{r}8.389 \\
(0.008)\end{array}$ \\
\hline \multicolumn{7}{|l|}{ Family characteristics: } \\
\hline $\begin{array}{l}\text { Age of highest earner } \\
\text { in HIU }\end{array}$ & $\begin{array}{l}36.567 \\
(0.018)\end{array}$ & $\begin{array}{l}36.545 \\
(0.020)\end{array}$ & $\begin{array}{l}36.763 \\
(0.013)\end{array}$ & $\begin{array}{l}36.961 \\
(0.015)\end{array}$ & $\begin{array}{l}36.978 \\
(0.012)\end{array}$ & $\begin{array}{l}37.139 \\
(0.012)\end{array}$ \\
\hline $\begin{array}{l}\text { Education of highest } \\
\text { earner in HIU }\end{array}$ & $\begin{array}{l}12.668 \\
(0.007)\end{array}$ & $\begin{array}{l}12.795 \\
(0.008\end{array}$ & $\begin{array}{l}12.694 \\
(0.005)\end{array}$ & $\begin{array}{l}12.862 \\
(0.006)\end{array}$ & $\begin{array}{l}12.941 \\
(0.004)\end{array}$ & $\begin{array}{l}12.940 \\
(0.005)\end{array}$ \\
\hline State unemployment rate & $\begin{array}{c}5.994 \\
(0.004)\end{array}$ & $\begin{array}{c}5.541 \\
(0.004)\end{array}$ & $\begin{array}{c}6.532 \\
(0.002)\end{array}$ & $\begin{array}{l}7.208 \\
(0.003)\end{array}$ & $\begin{array}{l}6.915 \\
(0.002)\end{array}$ & $\begin{array}{c}6.421 \\
(0.002)\end{array}$ \\
\hline Size of HIU & $\begin{array}{l}4.171 \\
(0.003)\end{array}$ & $\begin{array}{c}4.184 \\
(0.003)\end{array}$ & $\begin{array}{l}4.166 \\
(0.002)\end{array}$ & $\begin{array}{l}4.224 \\
(0.002)\end{array}$ & $\begin{array}{l}4.177 \\
(0.002)\end{array}$ & $\begin{array}{r}4.225 \\
(0.002)\end{array}$ \\
\hline Two parents & $\begin{array}{l}0.768 \\
(0.001)\end{array}$ & $\begin{array}{c}0.770 \\
(0.001)\end{array}$ & $\begin{array}{c}0.710 \\
(0.001)\end{array}$ & $\begin{array}{l}0.746 \\
(0.001)\end{array}$ & $\begin{array}{c}0.730 \\
(0.001)\end{array}$ & $\begin{array}{r}0.733 \\
(0.001)\end{array}$ \\
\hline Only a male head & $\begin{array}{c}0.024 \\
(0.000)\end{array}$ & $\begin{array}{c}0.018 \\
(0.000)\end{array}$ & $\begin{array}{c}0.027 \\
(0.000)\end{array}$ & $\begin{array}{c}0.029 \\
(0.000)\end{array}$ & $\begin{array}{c}0.026 \\
(0.000)\end{array}$ & $\begin{array}{c}0.022 \\
(0.000)\end{array}$ \\
\hline No earners & $\begin{array}{c}0.190 \\
(0.001)\end{array}$ & $\begin{array}{c}0.151 \\
(0.001)\end{array}$ & $\begin{array}{c}0.185 \\
(0.001)\end{array}$ & $\begin{array}{c}0.172 \\
(0.001)\end{array}$ & $\begin{array}{c}0.174 \\
(0.001)\end{array}$ & $\begin{array}{r}0.187 \\
(0.001)\end{array}$ \\
\hline One earner & $\begin{array}{c}0.392 \\
(0.001)\end{array}$ & $\begin{array}{c}0.411 \\
(0.001)\end{array}$ & $\begin{array}{c}0.412 \\
(0.001)\end{array}$ & $\begin{array}{c}0.411 \\
(0.001)\end{array}$ & $\begin{array}{c}0.406 \\
(0.001)\end{array}$ & $\begin{array}{r}0.396 \\
(0.001)\end{array}$ \\
\hline Two earners & $\begin{array}{c}0.362 \\
(0.001)\end{array}$ & $\begin{array}{c}0.385 \\
(0.001)\end{array}$ & $\begin{array}{c}0.356 \\
(0.001)\end{array}$ & $\begin{array}{c}0.370 \\
(0.001)\end{array}$ & $\begin{array}{c}0.374 \\
(0.001)\end{array}$ & $\begin{array}{c}0.373 \\
(0.001)\end{array}$ \\
\hline $\begin{array}{l}\text { Family income as percent } \\
\text { of poverty level }\end{array}$ & $\begin{array}{l}258.503 \\
(0.505)\end{array}$ & $\begin{array}{c}261.211 \\
(0.541)\end{array}$ & $\begin{array}{c}242.235 \\
(0.325)\end{array}$ & $\begin{array}{c}253.016 \\
(0.418)\end{array}$ & $\begin{array}{c}247.494 \\
(0.321)\end{array}$ & $\begin{array}{r}247.114 \\
(0.332)\end{array}$ \\
\hline Years covered & $87-88$ & $88-89$ & $90-91$ & $91-92$ & $92-94$ & $93-95$ \\
\hline Person-Months available & 195109 & 173222 & 428898 & 272977 & 441698 & 418836 \\
\hline
\end{tabular}

Notes: Summary statistics calculated for entire sample of children-regressions are run on a 50 percent sample or a sample of children in families with incomes less than 200 percent of the poverty line at the first month. Standard errors are in parentheses. 
Table 2: Coverage Type Regressions

\begin{tabular}{|c|c|c|c|c|c|c|}
\hline & \multicolumn{3}{|c|}{ Medicaid } & \multicolumn{3}{|c|}{ Private Insurance } \\
\hline & (1) & (2) & (3) & (4) & (5) & (6) \\
\hline Eligible & $\begin{array}{c}0.196 \\
(0.014)\end{array}$ & $\begin{array}{c}0.120 \\
(0.017)\end{array}$ & $\begin{array}{c}0.119 \\
(0.017)\end{array}$ & $\begin{array}{c}0.097 \\
(0.019)\end{array}$ & $\begin{array}{c}0.017 \\
(0.022)\end{array}$ & $\begin{array}{c}0.016 \\
(0.023)\end{array}$ \\
\hline Male & $\begin{array}{c}0.002 \\
(0.002)\end{array}$ & $\begin{array}{c}0.001 \\
(0.002)\end{array}$ & $\begin{array}{c}0.001 \\
(0.002)\end{array}$ & $\begin{array}{c}0.003 \\
(0.003)\end{array}$ & $\begin{array}{c}0.002 \\
(0.003)\end{array}$ & $\begin{array}{c}0.003 \\
(0.003)\end{array}$ \\
\hline White & $\begin{array}{l}-0.057 \\
(0.004)\end{array}$ & $\begin{array}{l}-0.067 \\
(0.004)\end{array}$ & $\begin{array}{l}-0.065 \\
(0.004)\end{array}$ & $\begin{array}{c}0.072 \\
(0.005)\end{array}$ & $\begin{array}{c}0.068 \\
(0.005)\end{array}$ & $\begin{array}{c}0.062 \\
(0.005)\end{array}$ \\
\hline $\begin{array}{l}\text { Age of highest earner } \\
\text { in HIU }\end{array}$ & $\begin{array}{c}-0.002 \\
(0.0002)\end{array}$ & $\begin{array}{c}-0.002 \\
(0.0002)\end{array}$ & & $\begin{array}{c}0.004 \\
(0.0003)\end{array}$ & $\begin{array}{c}0.004 \\
(0.0003)\end{array}$ & \\
\hline $\begin{array}{l}\text { Education of highest } \\
\text { earner in HIU }\end{array}$ & $\begin{array}{l}-0.011 \\
(0.001)\end{array}$ & $\begin{array}{l}-0.013 \\
(0.001)\end{array}$ & & $\begin{array}{c}0.037 \\
(0.001)\end{array}$ & $\begin{array}{c}0.033 \\
(0.001)\end{array}$ & \\
\hline State unemployment rate & $\begin{array}{c}0.002 \\
(0.001)\end{array}$ & $\begin{array}{l}-0.001 \\
(0.001)\end{array}$ & & $\begin{array}{l}-0.010 \\
(0.001)\end{array}$ & $\begin{array}{c}0.002 \\
(0.001)\end{array}$ & \\
\hline Size of HIU & $\begin{array}{c}0.026 \\
(0.001)\end{array}$ & $\begin{array}{c}0.029 \\
(0.001)\end{array}$ & $\begin{array}{c}0.033 \\
(0.002)\end{array}$ & $\begin{array}{l}-0.035 \\
(0.002)\end{array}$ & $\begin{array}{l}-0.031 \\
(0.002)\end{array}$ & $\begin{array}{l}-0.040 \\
(0.002)\end{array}$ \\
\hline Two parents & $\begin{array}{l}-0.191 \\
(0.005)\end{array}$ & $\begin{array}{l}-0.201 \\
(0.005)\end{array}$ & $\begin{array}{l}-0.221 \\
(0.006)\end{array}$ & $\begin{array}{c}0.117 \\
(0.006)\end{array}$ & $\begin{array}{c}0.109 \\
(0.006)\end{array}$ & $\begin{array}{c}0.156 \\
(0.007)\end{array}$ \\
\hline Only a male head & $\begin{array}{l}-0.169 \\
(0.008)\end{array}$ & $\begin{array}{l}-0.175 \\
(0.008)\end{array}$ & $\begin{array}{l}-0.182 \\
(0.008)\end{array}$ & $\begin{array}{c}0.071 \\
(0.012)\end{array}$ & $\begin{array}{c}0.069 \\
(0.012)\end{array}$ & $\begin{array}{c}0.083 \\
(0.012)\end{array}$ \\
\hline No earners & $\begin{array}{c}0.215 \\
(0.010)\end{array}$ & $\begin{array}{c}0.259 \\
(0.011)\end{array}$ & $\begin{array}{c}0.289 \\
(0.012)\end{array}$ & $\begin{array}{l}-0.649 \\
(0.013)\end{array}$ & $\begin{array}{l}-0.596 \\
(0.014)\end{array}$ & $\begin{array}{l}-0.671 \\
(0.016)\end{array}$ \\
\hline One earner & $\begin{array}{l}-0.022 \\
(0.004)\end{array}$ & $\begin{array}{l}-0.010 \\
(0.004)\end{array}$ & $\begin{array}{c}0.004 \\
(0.004)\end{array}$ & $\begin{array}{l}-0.147 \\
(0.006)\end{array}$ & $\begin{array}{l}-0.128 \\
(0.006)\end{array}$ & $\begin{array}{l}-0.161 \\
(0.006)\end{array}$ \\
\hline Two earners & $\begin{array}{l}-0.009 \\
(0.003) \\
\end{array}$ & $\begin{array}{l}-0.009 \\
(0.003) \\
\end{array}$ & $\begin{array}{l}-0.001 \\
(0.003) \\
\end{array}$ & $\begin{array}{l}-0.014 \\
(0.005) \\
\end{array}$ & $\begin{array}{l}-0.010 \\
(0.004) \\
\end{array}$ & $\begin{array}{l}-0.028 \\
(0.004) \\
\end{array}$ \\
\hline State dummies? & no & yes & yes & no & yes & yes \\
\hline $\mathrm{R}^{2}$ & 0.40 & 0.40 & 0.39 & 0.37 & 0.41 & 0.36 \\
\hline $\begin{array}{l}\text { Coeff. on FRACELIG } \\
\text { in first stage }\end{array}$ & $\begin{array}{c}0.785 \\
(0.014)\end{array}$ & $\begin{array}{c}0.773 \\
(0.016)\end{array}$ & $\begin{array}{c}0.771 \\
(0.017)\end{array}$ & $\begin{array}{c}0.785 \\
(0.014)\end{array}$ & $\begin{array}{c}0.773 \\
(0.016)\end{array}$ & $\begin{array}{c}0.771 \\
(0.017)\end{array}$ \\
\hline $\mathrm{N}_{\text {months }}, \mathrm{N}_{\text {indiv }}$ & & 965,371 & honths & ,345 ir & viduals & \\
\hline
\end{tabular}

Notes: Estimated from a 50 percent sample of children from the 1987-1993 SIPP panels, as described in the text. All regressions include age and year dummy variables. Standard errors (in parentheses) have been corrected for repeated observations within individuals and heteroskedasticity. 
Table 3: Mean Insurance Coverage of CPS and CPS Look-Alike Data from SIPP

\begin{tabular}{|c|c|c|c|c|c|c|}
\hline Year: & 1987 & 1988 & 1990 & 1991 & 1992 & 1993 \\
\hline \multicolumn{7}{|l|}{ Medicaid: } \\
\hline CPS & 0.159 & 0.154 & 0.187 & 0.210 & 0.225 & 0.247 \\
\hline \multicolumn{7}{|l|}{ SIPP } \\
\hline \multicolumn{7}{|l|}{ Using assumption: } \\
\hline Any time last year & 0.157 & 0.153 & 0.200 & 0.218 & 0.234 & 0.260 \\
\hline Last month & 0.107 & 0.105 & 0.147 & 0.153 & 0.168 & 0.198 \\
\hline Last 3 months & 0.120 & 0.115 & 0.160 & 0.168 & 0.184 & 0.223 \\
\hline Last 6 months & 0.134 & 0.136 & 0.180 & 0.193 & 0.213 & 0.241 \\
\hline Most of year & 0.115 & 0.113 & 0.146 & 0.163 & 0.169 & 0.198 \\
\hline \multicolumn{7}{|l|}{ Private: } \\
\hline CPS & 0.731 & 0.738 & 0.707 & 0.687 & 0.678 & 0.666 \\
\hline \multicolumn{7}{|l|}{ SIPP } \\
\hline \multicolumn{7}{|l|}{ Using assumption: } \\
\hline Any time last year & 0.805 & 0.795 & 0.762 & 0.769 & 0.765 & 0.734 \\
\hline Last month & 0.693 & 0.691 & 0.653 & 0.673 & 0.670 & 0.641 \\
\hline Last 3 months & 0.720 & 0.715 & 0.680 & 0.696 & 0.689 & 0.660 \\
\hline Last 6 months & 0.756 & 0.754 & 0.716 & 0.732 & 0.721 & 0.692 \\
\hline Most of year & 0.709 & 0.710 & 0.677 & 0.695 & 0.689 & 0.655 \\
\hline
\end{tabular}

Notes: Entries in the table are insurance coverage rates in the 1988-1989 and 1991-1994 CPS and coverage rates from children who provide at least six months of data within the first year of each SIPP panel, aggregated to the annual level under the listed assumptions. Since we do not use the 1989 panel, 1989 is omitted. 
Table 4: Comparing Eligibility Coefficients from CPS Data and SIPP CPS Look-Alike Data

\begin{tabular}{|c|c|c|c|c|}
\hline \multicolumn{3}{|c|}{ Medicaid } & \multicolumn{2}{|c|}{ Private } \\
\hline Corr. column in Table 2: & (2) & (3) & (5) & (6) \\
\hline State effects included? & no & yes & no & yes \\
\hline Results from CPS data & -- & 0.136 & -- & -0.070 \\
\hline & & $(0.013)$ & & $(0.016)$ \\
\hline \multicolumn{5}{|l|}{$\begin{array}{l}\text { Results from SIPP data: } \\
\text { I. First year of panel }\end{array}$} \\
\hline \multirow[t]{2}{*}{ Annual } & 0.158 & 0.160 & -0.031 & -0.045 \\
\hline & $(0.046)$ & $(0.046)$ & $(0.032)$ & $(0.039)$ \\
\hline \multirow[t]{2}{*}{ Last month } & 0.123 & 0.126 & -0.011 & -0.022 \\
\hline & $\begin{array}{c}(0.041) \\
0.144\end{array}$ & $\begin{array}{c}(0.042) \\
0.147\end{array}$ & $\begin{array}{l}(0.038) \\
0.0002\end{array}$ & $\begin{array}{l}(0.046) \\
-0.012\end{array}$ \\
\hline Last 3 months & $(0.046)$ & $(0.046)$ & $(0.036)$ & $(0.044)$ \\
\hline \multirow[t]{2}{*}{ Last 6 months } & 0.137 & 0.140 & -0.012 & -0.024 \\
\hline & $(0.048)$ & $(0.048)$ & $(0.030)$ & $(0.038)$ \\
\hline \multirow[t]{2}{*}{ Majority of year } & 0.127 & 0.129 & -0.025 & -0.037 \\
\hline & $(0.036)$ & $(0.036)$ & $(0.029)$ & $(0.038)$ \\
\hline \multicolumn{5}{|c|}{ II. First year, or surrounding $12 \mathrm{mos}$. } \\
\hline \multirow[t]{2}{*}{ Annual } & 0.177 & 0.181 & -0.023 & -0.041 \\
\hline & $(0.046)$ & $(0.046)$ & $(0.036)$ & $(0.044)$ \\
\hline \multirow[t]{2}{*}{ Last month } & 0.135 & 0.140 & -0.011 & -0.024 \\
\hline & $(0.041)$ & $(0.043)$ & $(0.037)$ & $(0.043)$ \\
\hline \multirow[t]{2}{*}{ Last 3 months } & 0.162 & 0.168 & 0.005 & -0.010 \\
\hline & $(0.045)$ & $(0.046)$ & $(0.034)$ & $(0.041)$ \\
\hline \multirow[t]{2}{*}{ Last 6 months } & 0.151 & 0.158 & -0.0004 & -0.015 \\
\hline & $(0.047)$ & $(0.047)$ & $(0.028)$ & $(0.036)$ \\
\hline \multirow[t]{2}{*}{ Majority of year } & 0.142 & 0.147 & -0.014 & -0.029 \\
\hline & $(0.036)$ & $(0.037)$ & $(0.027)$ & $(0.035)$ \\
\hline \multicolumn{5}{|c|}{ III. First year, or 6 mos. of data } \\
\hline \multirow[t]{2}{*}{ Annual } & 0.170 & 0.176 & -0.030 & -0.047 \\
\hline & $(0.045)$ & $(0.045)$ & $(0.032)$ & $(0.039)$ \\
\hline \multirow[t]{2}{*}{ Last month } & 0.136 & 0.141 & -0.015 & -0.027 \\
\hline & $(0.038)$ & $(0.040)$ & $(0.031)$ & $(0.037)$ \\
\hline \multirow[t]{2}{*}{ Last 3 months } & 0.157 & 0.163 & -0.003 & -0.015 \\
\hline & $(0.042)$ & $(0.043)$ & $(0.028)$ & $(0.034)$ \\
\hline \multirow[t]{2}{*}{ Last 6 months } & 0.148 & 0.154 & -0.011 & -0.026 \\
\hline & $(0.046)$ & $(0.046)$ & $(0.025)$ & $(0.032)$ \\
\hline \multirow[t]{2}{*}{ Majority of year } & 0.139 & 0.145 & -0.021 & -0.035 \\
\hline & $(0.033)$ & $(0.034)$ & $(0.022)$ & $(0.029)$ \\
\hline
\end{tabular}

Notes: Each entry in the table is the coefficient on eligibility from a regression on the look-alike sample created using the specified reference period assumption and data. "Annual" assumes the respondents answer the CPS insurance questions as posed, "last month" assumes the respondents' reference period is the last month of the period, "last 3 months" and "last 6 months" assume the respondents use a reference period of the previous 3 months and 6 months, respectively, and "majority of year" assumes the respondents answer the insurance questions according to the type of insurance they had for the most time in the previous year. 
Table 5: Coverage Type Regressions with Exogenous Eligibility Measure

\begin{tabular}{|c|c|c|c|c|c|c|c|c|}
\hline & \multicolumn{4}{|c|}{50 Percent Sample } & \multicolumn{4}{|c|}{$\begin{array}{c}\text { Poor Sample (Family Income }<200 \% \text { of } \\
\text { Poverty Level) }\end{array}$} \\
\hline & \multicolumn{2}{|c|}{ Medicaid } & \multicolumn{2}{|c|}{ Private } & \multicolumn{2}{|c|}{ Medicaid } & \multicolumn{2}{|c|}{ Private } \\
\hline & $(1)$ & $(2)$ & $(3)$ & $(4)$ & $(5)$ & $(6)$ & $(7)$ & $(8)$ \\
\hline Age-eligible & $\begin{array}{c}0.023 \\
(0.003)\end{array}$ & $\begin{array}{c}0.017 \\
(0.003)\end{array}$ & $\begin{array}{c}0.009 \\
(0.004)\end{array}$ & $\begin{array}{c}0.005 \\
(0.004)\end{array}$ & $\begin{array}{c}0.050 \\
(0.004)\end{array}$ & $\begin{array}{c}0.035 \\
(0.004)\end{array}$ & $\begin{array}{c}0.004 \\
(0.005)\end{array}$ & $\begin{array}{c}0.001 \\
(0.005)\end{array}$ \\
\hline Male & $\begin{array}{c}0.001 \\
(0.002)\end{array}$ & $\begin{array}{c}0.001 \\
(0.002)\end{array}$ & $\begin{array}{c}0.003 \\
(0.003)\end{array}$ & $\begin{array}{c}0.002 \\
(0.003)\end{array}$ & $\begin{array}{c}0.004 \\
(0.003)\end{array}$ & $\begin{array}{c}0.004 \\
(0.003)\end{array}$ & $\begin{array}{c}-0.00003 \\
(0.004)\end{array}$ & $\begin{array}{l}-0.0004 \\
(0.004)\end{array}$ \\
\hline White & $\begin{array}{l}-0.065 \\
(0.004)\end{array}$ & $\begin{array}{l}-0.073 \\
(0.004)\end{array}$ & $\begin{array}{c}0.068 \\
(0.004)\end{array}$ & $\begin{array}{c}0.067 \\
(0.005)\end{array}$ & $\begin{array}{l}-0.067 \\
(0.004)\end{array}$ & $\begin{array}{l}-0.085 \\
(0.004)\end{array}$ & $\begin{array}{c}0.051 \\
(0.004)\end{array}$ & $\begin{array}{c}0.055 \\
(0.005)\end{array}$ \\
\hline $\begin{array}{l}\text { Age of highest earner } \\
\text { in HIU }\end{array}$ & $\begin{array}{l}-0.003 \\
(0.000)\end{array}$ & $\begin{array}{l}-0.003 \\
(0.000)\end{array}$ & $\begin{array}{c}0.004 \\
(0.000)\end{array}$ & $\begin{array}{c}0.004 \\
(0.000)\end{array}$ & $\begin{array}{l}-0.004 \\
(0.000)\end{array}$ & $\begin{array}{c}-0.004 \\
(0.0002)\end{array}$ & $\begin{array}{c}0.004 \\
(0.0003)\end{array}$ & $\begin{array}{c}0.004 \\
(0.0003)\end{array}$ \\
\hline $\begin{array}{l}\text { Education of highest } \\
\text { earner in HIU }\end{array}$ & $\begin{array}{l}-0.015 \\
(0.000)\end{array}$ & $\begin{array}{l}-0.016 \\
(0.000)\end{array}$ & $\begin{array}{c}0.034 \\
(0.001)\end{array}$ & $\begin{array}{c}0.033 \\
(0.001)\end{array}$ & $\begin{array}{l}-0.016 \\
(0.001)\end{array}$ & $\begin{array}{l}-0.016 \\
(0.001)\end{array}$ & $\begin{array}{c}0.033 \\
(0.001)\end{array}$ & $\begin{array}{c}0.031 \\
(0.001)\end{array}$ \\
\hline $\begin{array}{l}\text { State unemployment } \\
\text { rate }\end{array}$ & $\begin{array}{c}0.003 \\
(0.001)\end{array}$ & $\begin{array}{l}-0.001 \\
(0.001)\end{array}$ & $\begin{array}{l}-0.009 \\
(0.001)\end{array}$ & $\begin{array}{c}0.002 \\
(0.001)\end{array}$ & $\begin{array}{c}0.005 \\
(0.001)\end{array}$ & $\begin{array}{l}-0.002 \\
(0.001)\end{array}$ & $\begin{array}{l}-0.013 \\
(0.001)\end{array}$ & $\begin{array}{c}0.002 \\
(0.001)\end{array}$ \\
\hline Size of HIU & $\begin{array}{c}0.036 \\
(0.001)\end{array}$ & $\begin{array}{c}0.035 \\
(0.001)\end{array}$ & $\begin{array}{l}-0.030 \\
(0.001)\end{array}$ & $\begin{array}{l}-0.030 \\
(0.001)\end{array}$ & $\begin{array}{c}0.037 \\
(0.001)\end{array}$ & $\begin{array}{c}0.035 \\
(0.001)\end{array}$ & $\begin{array}{l}-0.018 \\
(0.001)\end{array}$ & $\begin{array}{l}-0.018 \\
(0.001)\end{array}$ \\
\hline Two $\mathrm{p}$ & $\begin{array}{l}-0.220 \\
(0.005)\end{array}$ & $\begin{array}{l}-0.219 \\
(0.005)\end{array}$ & $\begin{array}{c}0.102 \\
(0.005)\end{array}$ & $\begin{array}{c}0.107 \\
(0.005)\end{array}$ & $\begin{array}{l}-0.224 \\
(0.005)\end{array}$ & $\begin{array}{l}-0.221 \\
(0.005)\end{array}$ & $\begin{array}{c}0.071 \\
(0.005)\end{array}$ & $\begin{array}{c}0.080 \\
(0.005)\end{array}$ \\
\hline Only a male head & $\begin{array}{c}-0.182 \\
(0.008)\end{array}$ & $\begin{array}{l}-0.183 \\
(0.008)\end{array}$ & $\begin{array}{c}0.064 \\
(0.012)\end{array}$ & $\begin{array}{c}0.067 \\
(0.012)\end{array}$ & $\begin{array}{l}-0.206 \\
(0.009)\end{array}$ & $\begin{array}{c}-0.209 \\
(0.009)\end{array}$ & $\begin{array}{c}0.053 \\
(0.012)\end{array}$ & $\begin{array}{c}0.058 \\
(0.012)\end{array}$ \\
\hline No earners & $\begin{array}{c}0.328 \\
(0.005)\end{array}$ & $\begin{array}{c}0.327 \\
(0.005)\end{array}$ & $\begin{array}{l}-0.593 \\
(0.006)\end{array}$ & $\begin{array}{l}-0.586 \\
(0.006)\end{array}$ & $\begin{array}{c}0.401 \\
(0.006)\end{array}$ & $\begin{array}{c}0.394 \\
(0.006)\end{array}$ & $\begin{array}{l}-0.555 \\
(0.010)\end{array}$ & $\begin{array}{l}-0.548 \\
(0.010)\end{array}$ \\
\hline One earner & $\begin{array}{c}0.004 \\
(0.003)\end{array}$ & $\begin{array}{c}0.006 \\
(0.003)\end{array}$ & $\begin{array}{l}-0.135 \\
(0.005)\end{array}$ & $\begin{array}{c}-0.126 \\
(0.005)\end{array}$ & $\begin{array}{c}0.066 \\
(0.005)\end{array}$ & $\begin{array}{c}0.068 \\
(0.005)\end{array}$ & $\begin{array}{c}-0.186 \\
(0.009)\end{array}$ & $\begin{array}{c}-0.176 \\
(0.009)\end{array}$ \\
\hline Two earners & $\begin{array}{c}-0.014 \\
(0.003) \\
\end{array}$ & $\begin{array}{c}-0.012 \\
(0.003) \\
\end{array}$ & $\begin{array}{r}-0.016 \\
(0.004) \\
\end{array}$ & $\begin{array}{r}-0.010 \\
(0.004) \\
\end{array}$ & $\begin{array}{c}0.009 \\
(0.005) \\
\end{array}$ & $\begin{array}{c}0.011 \\
(0.005) \\
\end{array}$ & $\begin{array}{c}-0.061 \\
(0.009) \\
\end{array}$ & $\begin{array}{c}-0.054 \\
(0.009) \\
\end{array}$ \\
\hline State dummies? & no & yes & no & yes & no & yes & no & yes \\
\hline $\mathrm{R}^{2}$ & 0.37 & 0.37 & 0.41 & 0.42 & 0.32 & 0.34 & 0.27 & 0.29 \\
\hline $\mathrm{N}_{\text {months }}, \mathrm{N}_{\text {individuals }}$ & \multicolumn{4}{|c|}{965,371 months, 34,345 individuals } & \multicolumn{4}{|c|}{915,969 months, 33,766 individuals } \\
\hline
\end{tabular}

Notes: Estimated from a sample of children from the 1987-1993 SIPP panels, as described in the text. All regressions include age and year dummy variables. Standard errors (in parentheses) have been corrected for repeated observations within individuals and heteroskedasticity. 
Table 6: Regressions Allowing Effect of Eligibility to Differ

\begin{tabular}{|c|c|c|c|c|}
\hline & \multicolumn{2}{|c|}{ Medicaid } & \multicolumn{2}{|c|}{ Private Insurance } \\
\hline & (1) & (2) & (3) & (4) \\
\hline $\begin{array}{l}\text { Eligible: } 5 \text { months } \\
\text { or more }\end{array}$ & $\begin{array}{c}0.231 \\
(0.016)\end{array}$ & $\begin{array}{c}0.156 \\
(0.019)\end{array}$ & $\begin{array}{c}0.105 \\
(0.022)\end{array}$ & $\begin{array}{c}0.020 \\
(0.025)\end{array}$ \\
\hline Eligible: first 4 months & $\begin{array}{l}-0.023 \\
(0.030)\end{array}$ & $\begin{array}{l}-0.061 \\
(0.030)\end{array}$ & $\begin{array}{c}0.123 \\
(0.038)\end{array}$ & $\begin{array}{c}0.024 \\
(0.037)\end{array}$ \\
\hline Male & $\begin{array}{c}0.003 \\
(0.002)\end{array}$ & $\begin{array}{c}0.002 \\
(0.002)\end{array}$ & $\begin{array}{c}0.004 \\
(0.003)\end{array}$ & $\begin{array}{c}0.003 \\
(0.003)\end{array}$ \\
\hline White & $\begin{array}{l}-0.055 \\
(0.004)\end{array}$ & $\begin{array}{l}-0.066 \\
(0.004)\end{array}$ & $\begin{array}{c}0.071 \\
(0.005)\end{array}$ & $\begin{array}{c}0.066 \\
(0.005)\end{array}$ \\
\hline $\begin{array}{l}\text { Age of highest earner } \\
\text { in HIU }\end{array}$ & $\begin{array}{c}-0.002 \\
(0.0002)\end{array}$ & $\begin{array}{c}-0.002 \\
(0.0003)\end{array}$ & $\begin{array}{c}0.004 \\
(0.0003)\end{array}$ & $\begin{array}{c}0.004 \\
(0.0003)\end{array}$ \\
\hline $\begin{array}{l}\text { Education of highest } \\
\text { earner in HIU }\end{array}$ & $\begin{array}{l}-0.010 \\
(0.001)\end{array}$ & $\begin{array}{l}-0.013 \\
(0.001)\end{array}$ & $\begin{array}{c}0.037 \\
(0.001)\end{array}$ & $\begin{array}{c}0.033 \\
(0.001)\end{array}$ \\
\hline State unemployment rate & $\begin{array}{c}0.001 \\
(0.001)\end{array}$ & $\begin{array}{l}-0.002 \\
(0.001)\end{array}$ & $\begin{array}{l}-0.010 \\
(0.001)\end{array}$ & $\begin{array}{c}0.003 \\
(0.001)\end{array}$ \\
\hline Size of HIU & $\begin{array}{c}0.024 \\
(0.001)\end{array}$ & $\begin{array}{c}0.028 \\
(0.002)\end{array}$ & $\begin{array}{l}-0.035 \\
(0.002)\end{array}$ & $\begin{array}{l}-0.031 \\
(0.002)\end{array}$ \\
\hline Two 1 & $\begin{array}{l}-0.177 \\
(0.006)\end{array}$ & $\begin{array}{l}-0.190 \\
(0.006)\end{array}$ & $\begin{array}{c}0.114 \\
(0.008)\end{array}$ & $\begin{array}{c}0.107 \\
(0.008)\end{array}$ \\
\hline Only a male head & $\begin{array}{l}-0.160 \\
(0.008)\end{array}$ & $\begin{array}{l}-0.167 \\
(0.008)\end{array}$ & $\begin{array}{c}0.069 \\
(0.013)\end{array}$ & $\begin{array}{c}0.067 \\
(0.012)\end{array}$ \\
\hline No earners & $\begin{array}{c}0.225 \\
(0.010)\end{array}$ & $\begin{array}{c}0.262 \\
(0.011)\end{array}$ & $\begin{array}{l}-0.665 \\
(0.014)\end{array}$ & $\begin{array}{l}-0.606 \\
(0.015)\end{array}$ \\
\hline One earner & $\begin{array}{l}-0.013 \\
(0.004)\end{array}$ & $\begin{array}{l}-0.003 \\
(0.004)\end{array}$ & $\begin{array}{l}-0.150 \\
(0.006)\end{array}$ & $\begin{array}{l}-0.130 \\
(0.006)\end{array}$ \\
\hline Two earners & $\begin{array}{l}-0.009 \\
(0.003) \\
\end{array}$ & $\begin{array}{l}-0.009 \\
(0.003) \\
\end{array}$ & $\begin{array}{l}-0.014 \\
(0.005) \\
\end{array}$ & $\begin{array}{l}-0.011 \\
(0.005) \\
\end{array}$ \\
\hline State dummies? & no & yes & no & yes \\
\hline $\mathrm{R}^{2}$ & 0.43 & 0.43 & 0.37 & 0.41 \\
\hline $\begin{array}{l}\text { Reject that effects same? } \\
\text { (p-value) }\end{array}$ & $\begin{array}{c}\text { yes } \\
(0.000)\end{array}$ & $\begin{array}{c}\text { yes } \\
(0.000)\end{array}$ & $\begin{array}{c}\text { no } \\
(0.662)\end{array}$ & $\begin{array}{c}\text { no } \\
(0.919)\end{array}$ \\
\hline $\mathrm{N}_{\text {months }}, \mathrm{N}_{\text {individuals }}$ & 828,444 & months, & 33,613 ind & ividuals \\
\hline
\end{tabular}

Notes: Estimated from a 50 percent sample of children from the 1987-1993 SIPP panels, as described in the text. Variables included in first stage and omitted from second stage are FRACELIG $_{t}$, FRACELIG $_{\mathrm{t}-1}, \mathrm{FRACELIG}_{\mathrm{t}-2}$, and FRACELIG $\mathrm{FR}_{\mathrm{t}-3}$. All regressions include age and year dummy variables. Standard errors (in parentheses) have been corrected for repeated observations within individuals and heteroskedasticity. 


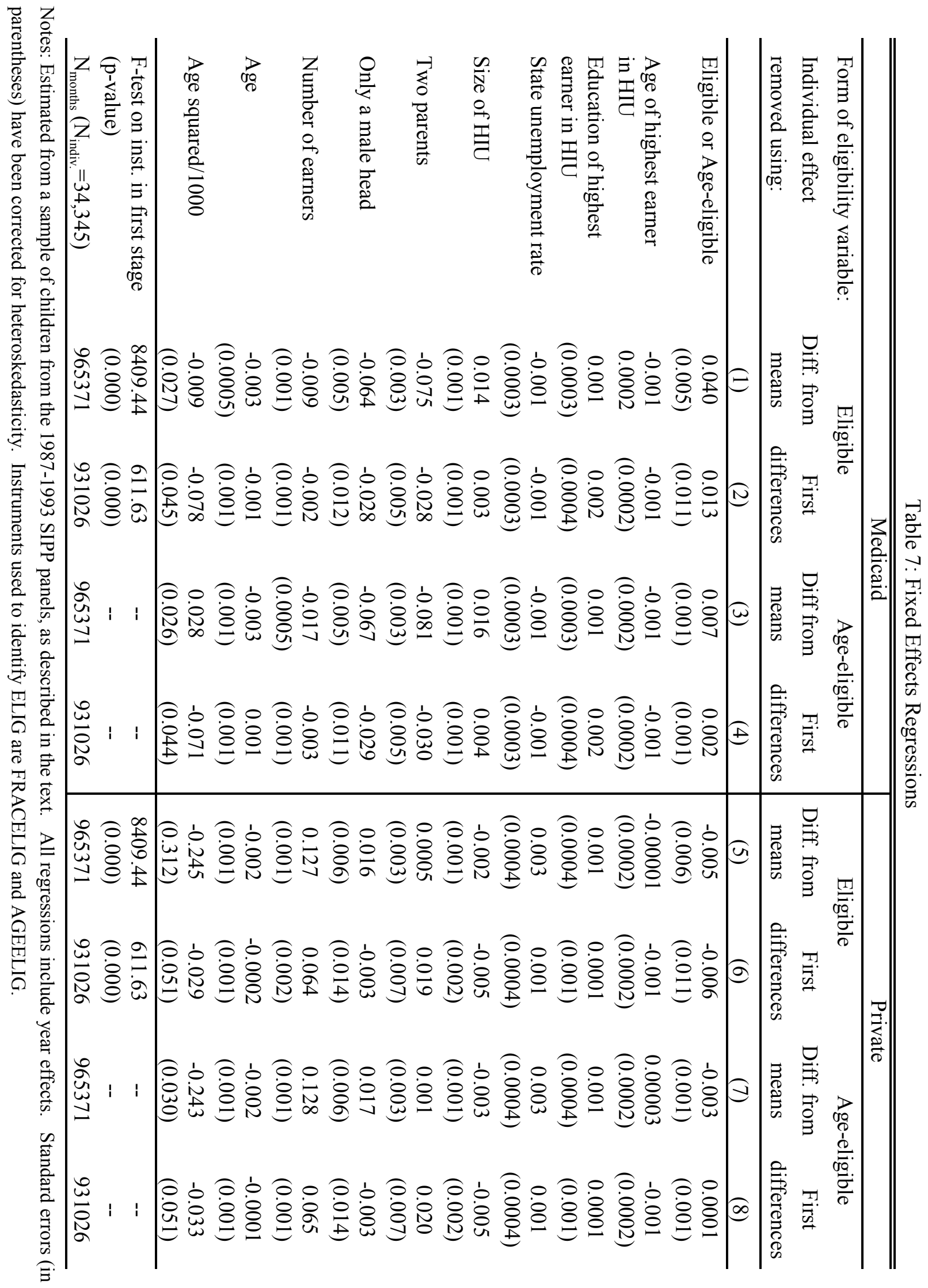




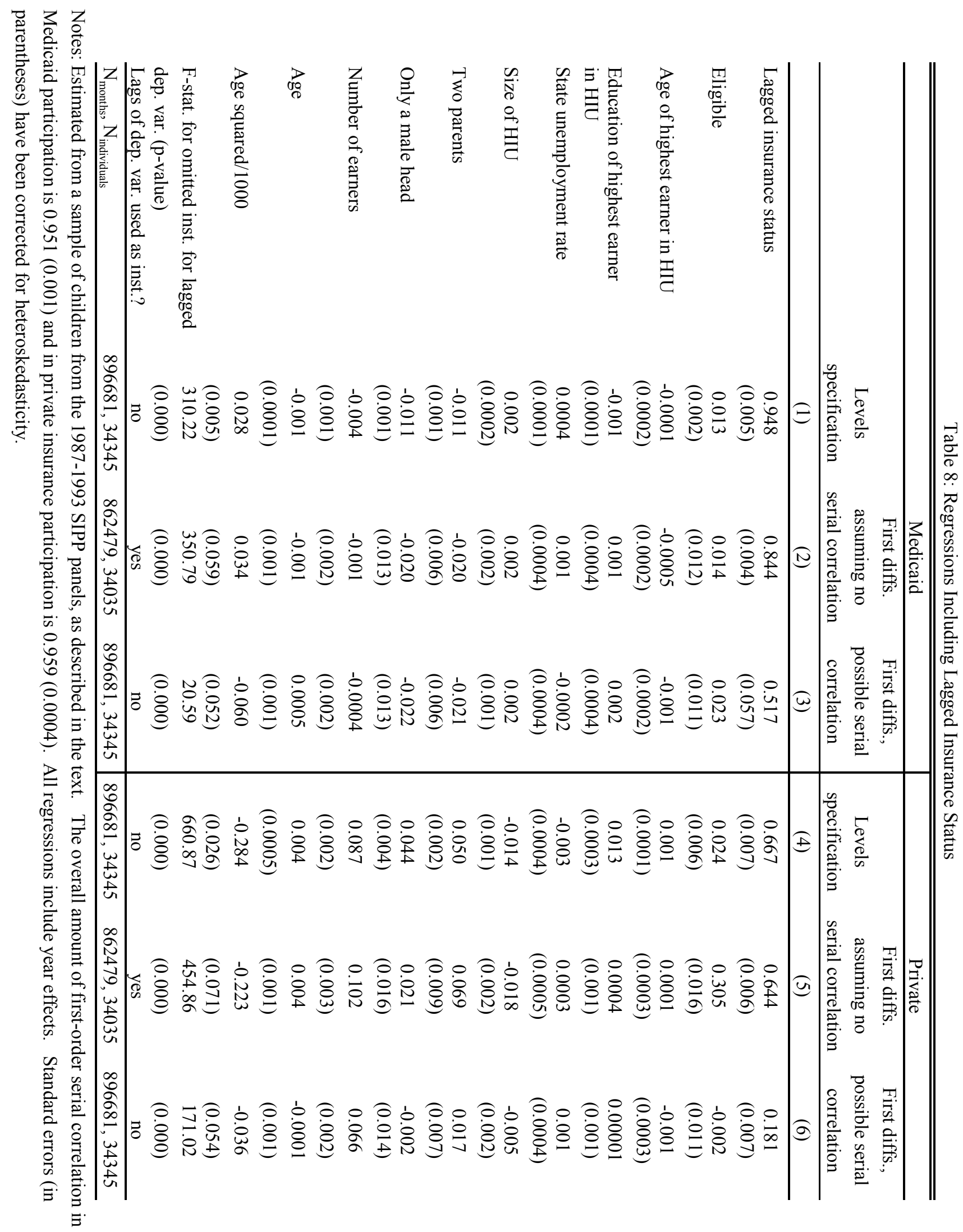




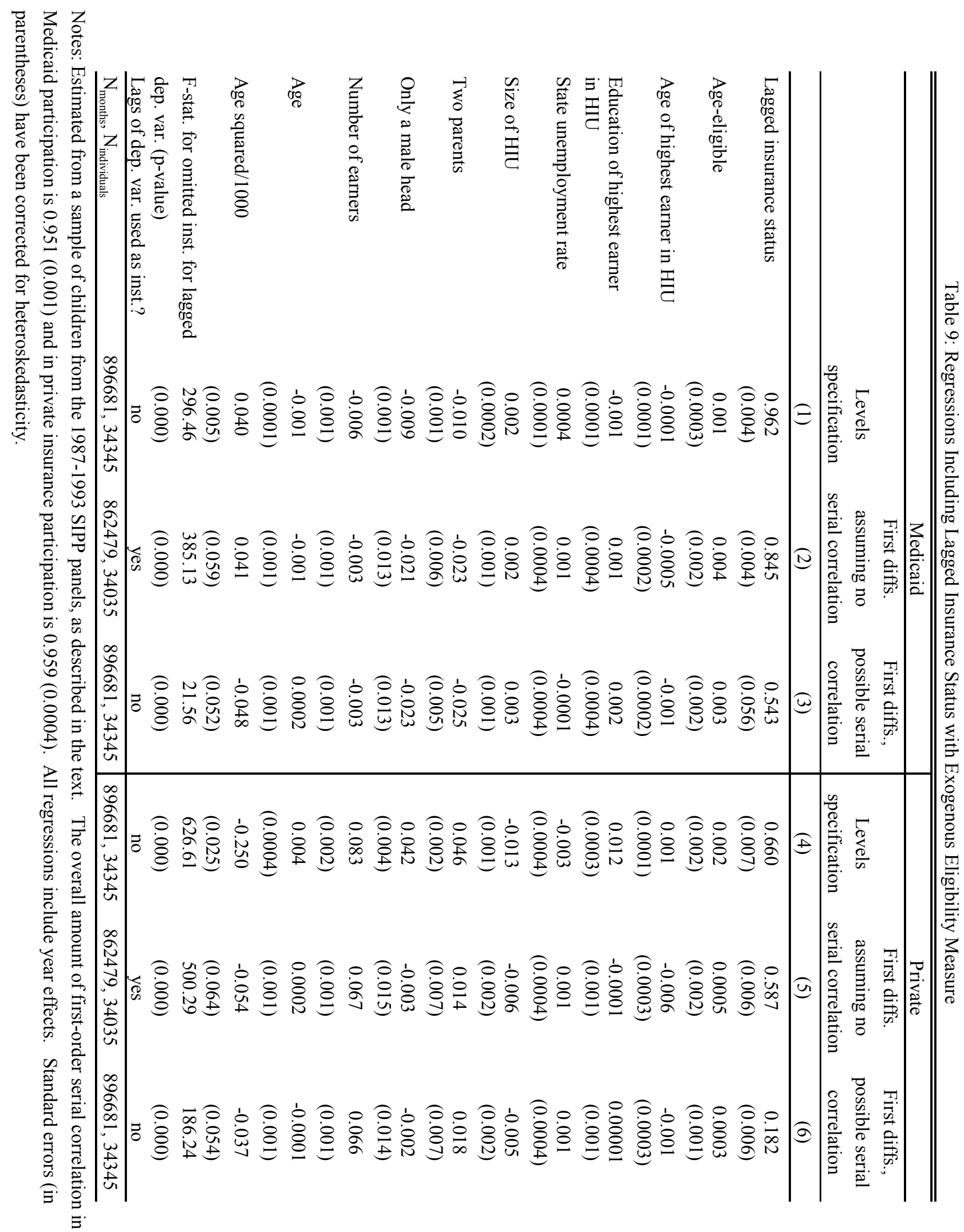


Appendix Table A1: Coverage Type Regressions, Four-Month Observations

\begin{tabular}{|c|c|c|c|c|c|c|}
\hline & & Medicaid & & Priy & ate Insura & nce \\
\hline & (1) & (2) & (3) & (4) & $(5)$ & (6) \\
\hline Eligible & $\begin{array}{c}0.199 \\
(0.010)\end{array}$ & $\begin{array}{c}0.134 \\
(0.012)\end{array}$ & $\begin{array}{c}0.135 \\
(0.012)\end{array}$ & $\begin{array}{c}0.084 \\
(0.014)\end{array}$ & $\begin{array}{l}-0.001 \\
(0.016)\end{array}$ & $\begin{array}{l}-0.007 \\
(0.017)\end{array}$ \\
\hline Male & $\begin{array}{c}0.002 \\
(0.002)\end{array}$ & $\begin{array}{c}0.001 \\
(0.002)\end{array}$ & $\begin{array}{c}0.001 \\
(0.002)\end{array}$ & $\begin{array}{c}0.001 \\
(0.002)\end{array}$ & $\begin{array}{l}0.0003 \\
(0.002)\end{array}$ & $\begin{array}{c}0.001 \\
(0.002)\end{array}$ \\
\hline White & $\begin{array}{l}-0.057 \\
(0.003)\end{array}$ & $\begin{array}{l}-0.066 \\
(0.003)\end{array}$ & $\begin{array}{l}-0.064 \\
(0.003)\end{array}$ & $\begin{array}{c}0.075 \\
(0.003)\end{array}$ & $\begin{array}{c}0.070 \\
(0.003)\end{array}$ & $\begin{array}{c}0.065 \\
(0.003)\end{array}$ \\
\hline $\begin{array}{l}\text { Age of highest earner } \\
\text { in HIU }\end{array}$ & $\begin{array}{c}-0.002 \\
(0.0002)\end{array}$ & $\begin{array}{c}-0.002 \\
(0.0002)\end{array}$ & & $\begin{array}{c}0.004 \\
(0.0002)\end{array}$ & $\begin{array}{c}0.004 \\
(0.0002)\end{array}$ & \\
\hline $\begin{array}{l}\text { Education of highest } \\
\text { earner in HIU }\end{array}$ & $\begin{array}{c}-0.011 \\
(0.0004)\end{array}$ & $\begin{array}{c}-0.013 \\
(0.0004)\end{array}$ & & $\begin{array}{c}0.038 \\
(0.001)\end{array}$ & $\begin{array}{c}0.034 \\
(0.001)\end{array}$ & \\
\hline State unemployment rate & $\begin{array}{c}0.003 \\
(0.001)\end{array}$ & $\begin{array}{l}-0.001 \\
(0.001)\end{array}$ & & $\begin{array}{l}-0.010 \\
(0.001)\end{array}$ & $\begin{array}{c}0.003 \\
(0.001)\end{array}$ & \\
\hline Size of HIU & $\begin{array}{c}0.026 \\
(0.001)\end{array}$ & $\begin{array}{c}0.030 \\
(0.001)\end{array}$ & $\begin{array}{c}0.033 \\
(0.001)\end{array}$ & $\begin{array}{l}-0.035 \\
(0.001)\end{array}$ & $\begin{array}{l}-0.030 \\
(0.001)\end{array}$ & $\begin{array}{l}-0.040 \\
(0.001)\end{array}$ \\
\hline Two parents & $\begin{array}{l}-0.197 \\
(0.004)\end{array}$ & $\begin{array}{l}-0.207 \\
(0.004)\end{array}$ & $\begin{array}{l}-0.227 \\
(0.004)\end{array}$ & $\begin{array}{c}0.129 \\
(0.005)\end{array}$ & $\begin{array}{c}0.119 \\
(0.005)\end{array}$ & $\begin{array}{c}0.166 \\
(0.005)\end{array}$ \\
\hline Only a male head & $\begin{array}{l}-0.170 \\
(0.006)\end{array}$ & $\begin{array}{l}-0.176 \\
(0.006)\end{array}$ & $\begin{array}{l}-0.183 \\
(0.006)\end{array}$ & $\begin{array}{c}0.060 \\
(0.009)\end{array}$ & $\begin{array}{c}0.059 \\
(0.008)\end{array}$ & $\begin{array}{c}0.074 \\
(0.009)\end{array}$ \\
\hline No earners & $\begin{array}{c}0.204 \\
(0.007)\end{array}$ & $\begin{array}{c}0.239 \\
(0.008)\end{array}$ & $\begin{array}{c}0.265 \\
(0.008)\end{array}$ & $\begin{array}{l}-0.609 \\
(0.009)\end{array}$ & $\begin{array}{l}-0.555 \\
(0.010)\end{array}$ & $\begin{array}{l}-0.624 \\
(0.011)\end{array}$ \\
\hline One earner & $\begin{array}{l}-0.021 \\
(0.003)\end{array}$ & $\begin{array}{l}-0.012 \\
(0.003)\end{array}$ & $\begin{array}{l}0.0003 \\
(0.003)\end{array}$ & $\begin{array}{l}-0.141 \\
(0.004)\end{array}$ & $\begin{array}{l}-0.121 \\
(0.004)\end{array}$ & $\begin{array}{l}-0.151 \\
(0.005)\end{array}$ \\
\hline Two earners & $\begin{array}{l}-0.007 \\
(0.002) \\
\end{array}$ & $\begin{array}{l}-0.007 \\
(0.002) \\
\end{array}$ & $\begin{array}{c}0.00004 \\
(0.002) \\
\end{array}$ & $\begin{array}{l}-0.019 \\
(0.003) \\
\end{array}$ & $\begin{array}{l}-0.015 \\
(0.003) \\
\end{array}$ & $\begin{array}{l}-0.032 \\
(0.003) \\
\end{array}$ \\
\hline State dummies? & no & yes & yes & no & yes & yes \\
\hline $\mathrm{R}^{2}$ & 0.40 & 0.40 & 0.39 & 0.36 & 0.41 & 0.36 \\
\hline Coeff. on FRACELIG & 0.780 & 0.791 & 0.788 & 0.780 & 0.791 & 0.788 \\
\hline in first stage & $(0.010)$ & $(0.012)$ & $(0.012)$ & $(0.010)$ & $(0.012)$ & $(0.012)$ \\
\hline
\end{tabular}

Notes: Estimated from the entire sample of children from the 1987-1993 SIPP panels using only the last month of each wave, as described in the text. All regressions include age and year dummy variables. Standard errors (in parentheses) have been corrected for repeated observations within individuals and heteroskedasticity. 
Appendix Table A2: Coverage Type Regressions with Exogenous Eligibility Measure,

Four-Month Observations

\begin{tabular}{|c|c|c|c|c|c|c|c|c|}
\hline & \multicolumn{4}{|c|}{ Entire Sample } & \multicolumn{4}{|c|}{$\begin{array}{c}\text { Poor Sample (Family Income }<200 \% \text { of } \\
\text { Poverty Level) }\end{array}$} \\
\hline & \multicolumn{2}{|c|}{ Medicaid } & \multicolumn{2}{|c|}{ Private } & \multicolumn{2}{|c|}{ Medicaid } & \multicolumn{2}{|c|}{ Private } \\
\hline & $(1)$ & $(2)$ & $(3)$ & $(4)$ & $(5)$ & $(6)$ & $(7)$ & $(8)$ \\
\hline Age-eligible & $\begin{array}{c}0.024 \\
(0.002)\end{array}$ & $\begin{array}{c}0.017 \\
(0.002)\end{array}$ & $\begin{array}{c}0.003 \\
(0.003)\end{array}$ & $\begin{array}{l}0.0004 \\
(0.003)\end{array}$ & $\begin{array}{c}0.051 \\
(0.005)\end{array}$ & $\begin{array}{c}0.035 \\
(0.005)\end{array}$ & $\begin{array}{c}0.005 \\
(0.006)\end{array}$ & $\begin{array}{c}0.002 \\
(0.005)\end{array}$ \\
\hline Male & $\begin{array}{c}0.001 \\
(0.002)\end{array}$ & $\begin{array}{c}0.001 \\
(0.002)\end{array}$ & $\begin{array}{l}0.0003 \\
(0.002)\end{array}$ & $\begin{array}{l}0.0003 \\
(0.002)\end{array}$ & $\begin{array}{c}0.004 \\
(0.003)\end{array}$ & $\begin{array}{c}0.003 \\
(0.003)\end{array}$ & $\begin{array}{c}0.001 \\
(0.004)\end{array}$ & $\begin{array}{l}0.0002 \\
(0.004)\end{array}$ \\
\hline White & $\begin{array}{l}-0.066 \\
(0.003)\end{array}$ & $\begin{array}{l}-0.073 \\
(0.003)\end{array}$ & $\begin{array}{c}0.071 \\
(0.003)\end{array}$ & $\begin{array}{c}0.070 \\
(0.003)\end{array}$ & $\begin{array}{l}-0.067 \\
(0.004)\end{array}$ & $\begin{array}{l}-0.085 \\
(0.004)\end{array}$ & $\begin{array}{c}0.052 \\
(0.005)\end{array}$ & $\begin{array}{c}0.056 \\
(0.005)\end{array}$ \\
\hline $\begin{array}{l}\text { Age of highest earner } \\
\text { in HIU }\end{array}$ & $\begin{array}{c}-0.003 \\
(0.0002)\end{array}$ & $\begin{array}{c}-0.003 \\
(0.0002)\end{array}$ & $\begin{array}{c}0.004 \\
(0.0002)\end{array}$ & $\begin{array}{c}0.004 \\
(0.0002)\end{array}$ & $\begin{array}{c}-0.004 \\
(0.0003)\end{array}$ & $\begin{array}{c}-0.004 \\
(0.0002)\end{array}$ & $\begin{array}{c}0.004 \\
(0.0003)\end{array}$ & $\begin{array}{c}0.004 \\
(0.0003)\end{array}$ \\
\hline $\begin{array}{l}\text { Education of highest } \\
\text { earner in HIU }\end{array}$ & $\begin{array}{l}-0.016 \\
(0.0003)\end{array}$ & $\begin{array}{l}-0.016 \\
(0.0003)\end{array}$ & $\begin{array}{c}0.036 \\
(0.0004)\end{array}$ & $\begin{array}{c}0.034 \\
(0.0004)\end{array}$ & $\begin{array}{c}-0.017 \\
(0.001)\end{array}$ & $\begin{array}{l}-0.017 \\
(0.001)\end{array}$ & $\begin{array}{c}0.034 \\
(0.001)\end{array}$ & $\begin{array}{c}0.032 \\
(0.001)\end{array}$ \\
\hline $\begin{array}{l}\text { State unemployment } \\
\text { rate }\end{array}$ & $\begin{array}{c}0.004 \\
(0.001)\end{array}$ & $\begin{array}{l}-0.001 \\
(0.001)\end{array}$ & $\begin{array}{l}-0.009 \\
(0.001)\end{array}$ & $\begin{array}{c}0.003 \\
(0.001)\end{array}$ & $\begin{array}{c}0.006 \\
(0.001)\end{array}$ & $\begin{array}{l}-0.002 \\
(0.001)\end{array}$ & $\begin{array}{l}-0.014 \\
(0.001)\end{array}$ & $\begin{array}{c}0.001 \\
(0.002)\end{array}$ \\
\hline Size of HIU & $\begin{array}{c}0.037 \\
(0.001)\end{array}$ & $\begin{array}{c}0.036 \\
(0.001)\end{array}$ & $\begin{array}{l}-0.030 \\
(0.001)\end{array}$ & $\begin{array}{l}-0.030 \\
(0.001)\end{array}$ & $\begin{array}{c}0.038 \\
(0.001)\end{array}$ & $\begin{array}{c}0.036 \\
(0.001)\end{array}$ & $\begin{array}{l}-0.018 \\
(0.001)\end{array}$ & $\begin{array}{l}-0.018 \\
(0.001)\end{array}$ \\
\hline Two $\mathrm{p}$ & $\begin{array}{l}-0.230 \\
(0.003)\end{array}$ & $\begin{array}{l}-0.229 \\
(0.003)\end{array}$ & $\begin{array}{c}0.115 \\
(0.004)\end{array}$ & $\begin{array}{c}0.119 \\
(0.004)\end{array}$ & $\begin{array}{l}-0.235 \\
(0.005)\end{array}$ & $\begin{array}{l}-0.231 \\
(0.005)\end{array}$ & $\begin{array}{c}0.080 \\
(0.005)\end{array}$ & $\begin{array}{c}0.089 \\
(0.005)\end{array}$ \\
\hline Only a male head & $\begin{array}{l}-0.183 \\
(0.006)\end{array}$ & $\begin{array}{l}-0.184 \\
(0.006)\end{array}$ & $\begin{array}{c}0.055 \\
(0.008)\end{array}$ & $\begin{array}{c}0.059 \\
(0.008)\end{array}$ & $\begin{array}{c}-0.212 \\
(0.009)\end{array}$ & $\begin{array}{l}-0.216 \\
(0.009)\end{array}$ & $\begin{array}{c}0.057 \\
(0.012)\end{array}$ & $\begin{array}{c}0.062 \\
(0.012)\end{array}$ \\
\hline No earners & $\begin{array}{c}0.312 \\
(0.004)\end{array}$ & $\begin{array}{c}0.310 \\
(0.004)\end{array}$ & $\begin{array}{c}-0.564 \\
(0.005)\end{array}$ & $\begin{array}{c}-0.556 \\
(0.004)\end{array}$ & $\begin{array}{c}0.393 \\
(0.007)\end{array}$ & $\begin{array}{c}0.386 \\
(0.007)\end{array}$ & $\begin{array}{c}-0.536 \\
(0.010)\end{array}$ & $\begin{array}{c}-0.530 \\
(0.010)\end{array}$ \\
\hline One earner & $\begin{array}{c}0.004 \\
(0.002)\end{array}$ & $\begin{array}{c}0.005 \\
(0.002)\end{array}$ & $\begin{array}{c}-0.130 \\
(0.004)\end{array}$ & $\begin{array}{c}-0.122 \\
(0.004)\end{array}$ & $\begin{array}{c}0.065 \\
(0.006)\end{array}$ & $\begin{array}{c}0.067 \\
(0.006)\end{array}$ & $\begin{array}{c}-0.180 \\
(0.010)\end{array}$ & $\begin{array}{l}-0.170 \\
(0.009)\end{array}$ \\
\hline Two earners & $\begin{array}{l}-0.012 \\
(0.002) \\
\end{array}$ & $\begin{array}{l}-0.011 \\
(0.002) \\
\end{array}$ & $\begin{array}{l}-0.021 \\
(0.003) \\
\end{array}$ & $\begin{array}{l}-0.015 \\
(0.003) \\
\end{array}$ & $\begin{array}{c}0.008 \\
(0.005) \\
\end{array}$ & $\begin{array}{c}0.010 \\
(0.005) \\
\end{array}$ & $\begin{array}{l}-0.061 \\
(0.009) \\
\end{array}$ & $\begin{array}{l}-0.054 \\
(0.009) \\
\end{array}$ \\
\hline State dummies? & no & yes & no & yes & no & yes & no & yes \\
\hline $\mathrm{R}^{2}$ & 0.36 & 0.37 & 0.40 & 0.41 & 0.33 & 0.34 & 0.27 & 0.28 \\
\hline $\mathrm{N}_{\text {months }}, \mathrm{N}_{\text {individuals }}$ & \multicolumn{4}{|c|}{483,637 months, 68,635 individuals } & \multicolumn{4}{|c|}{229,543 months, 33717 individuals } \\
\hline
\end{tabular}

Notes: Estimated from the entire sample and a low-income sample of children from the 1987-1993 SIPP panels using only the last month of each wave, as described in the text. All regressions include age and year dummy variables.

Standard errors (in parentheses) have been corrected for repeated observations within individuals and heteroskedasticity. 
Appendix Table A3: Regressions Allowing Effect of Eligibility to Differ, Four-Month Observations

\begin{tabular}{|c|c|c|c|c|}
\hline & \multicolumn{2}{|c|}{ Medicaid } & \multicolumn{2}{|c|}{ Private Insurance } \\
\hline & (1) & (2) & & \\
\hline $\begin{array}{l}\text { Eligible: } 2 \text { waves } \\
\text { or more }\end{array}$ & $\begin{array}{c}0.224 \\
(0.011)\end{array}$ & $\begin{array}{c}0.158 \\
(0.014)\end{array}$ & $\begin{array}{c}0.085 \\
(0.015)\end{array}$ & $\begin{array}{l}-0.007 \\
(0.018)\end{array}$ \\
\hline Eligible: first wave & $\begin{array}{l}-0.002 \\
(0.024)\end{array}$ & $\begin{array}{l}-0.045 \\
(0.024)\end{array}$ & $\begin{array}{c}0.154 \\
(0.031)\end{array}$ & $\begin{array}{c}0.059 \\
(0.029)\end{array}$ \\
\hline Male & $\begin{array}{c}0.002 \\
(0.002)\end{array}$ & $\begin{array}{c}0.002 \\
(0.002)\end{array}$ & $\begin{array}{c}0.001 \\
(0.002)\end{array}$ & $\begin{array}{l}0.0005 \\
(0.002)\end{array}$ \\
\hline White & $\begin{array}{l}-0.056 \\
(0.003)\end{array}$ & $\begin{array}{l}-0.065 \\
(0.003)\end{array}$ & $\begin{array}{c}0.075 \\
(0.003)\end{array}$ & $\begin{array}{c}0.069 \\
(0.003)\end{array}$ \\
\hline $\begin{array}{l}\text { Age of highest earner } \\
\text { in HIU }\end{array}$ & $\begin{array}{c}-0.002 \\
(0.0002)\end{array}$ & $\begin{array}{c}-0.002 \\
(0.0002)\end{array}$ & $\begin{array}{c}0.004 \\
(0.0002)\end{array}$ & $\begin{array}{c}0.004 \\
(0.0002)\end{array}$ \\
\hline $\begin{array}{l}\text { Education of highest } \\
\text { earner in HIU }\end{array}$ & $\begin{array}{c}-0.011 \\
(0.0004)\end{array}$ & $\begin{array}{c}-0.012 \\
(0.0005)\end{array}$ & $\begin{array}{c}0.038 \\
(0.001)\end{array}$ & $\begin{array}{c}0.034 \\
(0.001)\end{array}$ \\
\hline State unemployment rate & $\begin{array}{c}0.002 \\
(0.001)\end{array}$ & $\begin{array}{l}-0.002 \\
(0.001)\end{array}$ & $\begin{array}{l}-0.010 \\
(0.001)\end{array}$ & $\begin{array}{c}0.004 \\
(0.001)\end{array}$ \\
\hline Size of HIU & $\begin{array}{c}0.025 \\
(0.001)\end{array}$ & $\begin{array}{c}0.028 \\
(0.001)\end{array}$ & $\begin{array}{l}-0.035 \\
(0.001)\end{array}$ & $\begin{array}{l}-0.030 \\
(0.001)\end{array}$ \\
\hline Two parents & $\begin{array}{l}-0.184 \\
(0.004)\end{array}$ & $\begin{array}{l}-0.196 \\
(0.005)\end{array}$ & $\begin{array}{c}0.123 \\
(0.006)\end{array}$ & $\begin{array}{c}0.112 \\
(0.006)\end{array}$ \\
\hline Only a male head & $\begin{array}{l}-0.162 \\
(0.006)\end{array}$ & $\begin{array}{l}-0.168 \\
(0.006)\end{array}$ & $\begin{array}{c}0.057 \\
(0.009)\end{array}$ & $\begin{array}{c}0.055 \\
(0.009)\end{array}$ \\
\hline No earners & $\begin{array}{c}0.207 \\
(0.007)\end{array}$ & $\begin{array}{c}0.238 \\
(0.008)\end{array}$ & $\begin{array}{l}-0.625 \\
(0.010)\end{array}$ & $\begin{array}{l}-0.566 \\
(0.010)\end{array}$ \\
\hline One earner & $\begin{array}{l}-0.011 \\
(0.003)\end{array}$ & $\begin{array}{l}-0.004 \\
(0.003)\end{array}$ & $\begin{array}{l}-0.145 \\
(0.004)\end{array}$ & $\begin{array}{l}-0.125 \\
(0.004)\end{array}$ \\
\hline Two earners & $\begin{array}{l}-0.006 \\
(0.002) \\
\end{array}$ & $\begin{array}{l}-0.006 \\
(0.002) \\
\end{array}$ & $\begin{array}{l}-0.019 \\
(0.003) \\
\end{array}$ & $\begin{array}{c}-0.016 \\
(0.003) \\
\end{array}$ \\
\hline State dummies? & no & yes & no & yes \\
\hline $\mathrm{R}^{2}$ & 0.42 & 0.41 & 0.37 & 0.41 \\
\hline $\begin{array}{l}\text { Reject that effects same? } \\
\text { (p-value) }\end{array}$ & $\begin{array}{c}\text { yes } \\
(0.000)\end{array}$ & $\begin{array}{c}\text { yes } \\
(0.000)\end{array}$ & $\begin{array}{c}\text { yes } \\
(0.031)\end{array}$ & $\begin{array}{c}\text { yes } \\
(0.032)\end{array}$ \\
\hline, $\mathrm{N}_{\mathrm{ir}}$ & 828,4 & lonths &, 613 i & jiduals \\
\hline
\end{tabular}

Notes: Estimated from the entire sample of children from the 1987-1993 SIPP panels using only the last month of each wave, as described in the text. Variables included in first stage and omitted from second stage are FRACELIG ${ }_{\mathrm{t}}, \mathrm{FRACELIG}_{\mathrm{t}-1}, \mathrm{FRACELIG}_{\mathrm{t}-2}$, and $\mathrm{FRACELIG}_{\mathrm{t}-3}$. All regressions include age and year dummy variables. Standard errors (in parentheses) have been corrected for repeated observations within individuals and heteroskedasticity. 


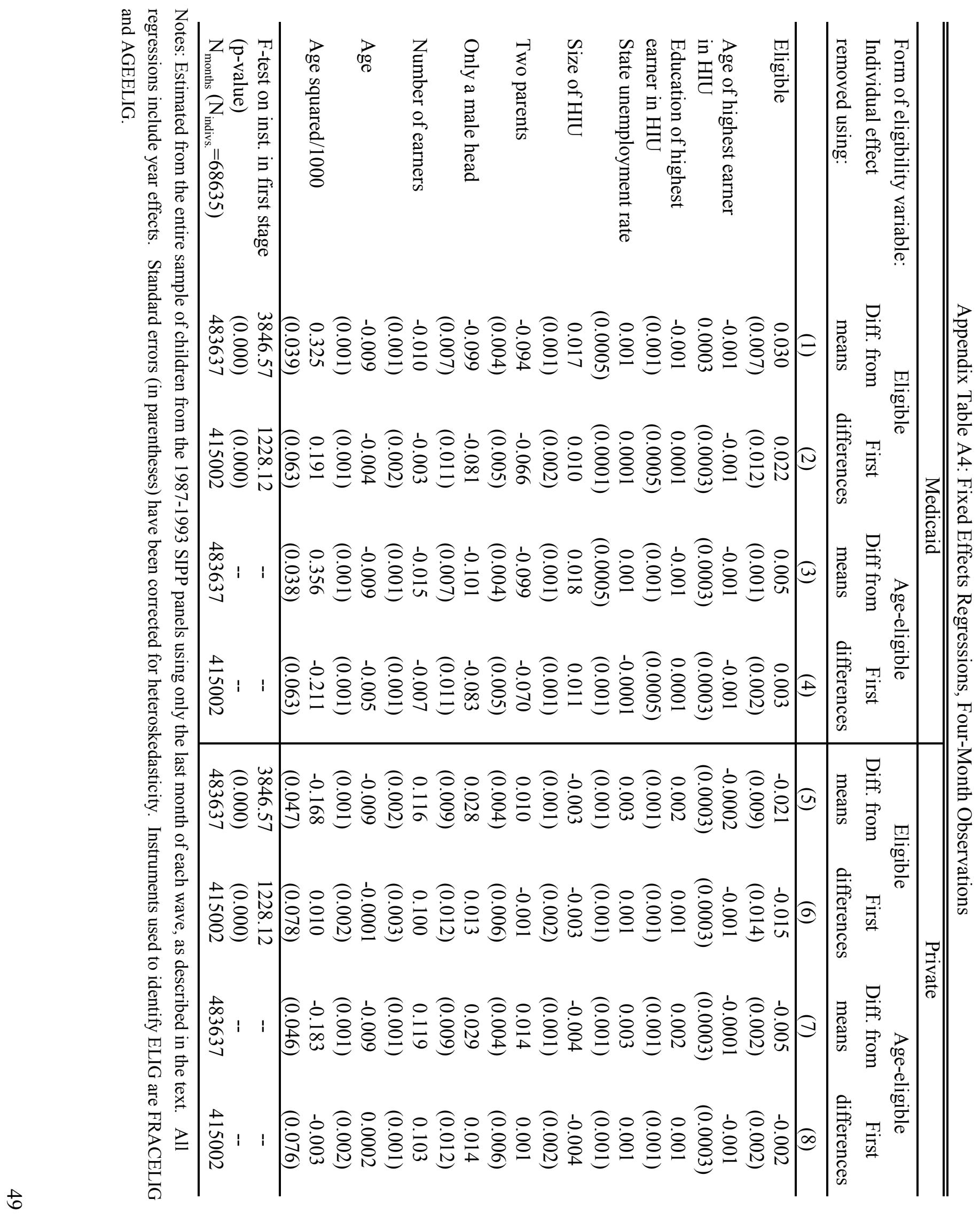




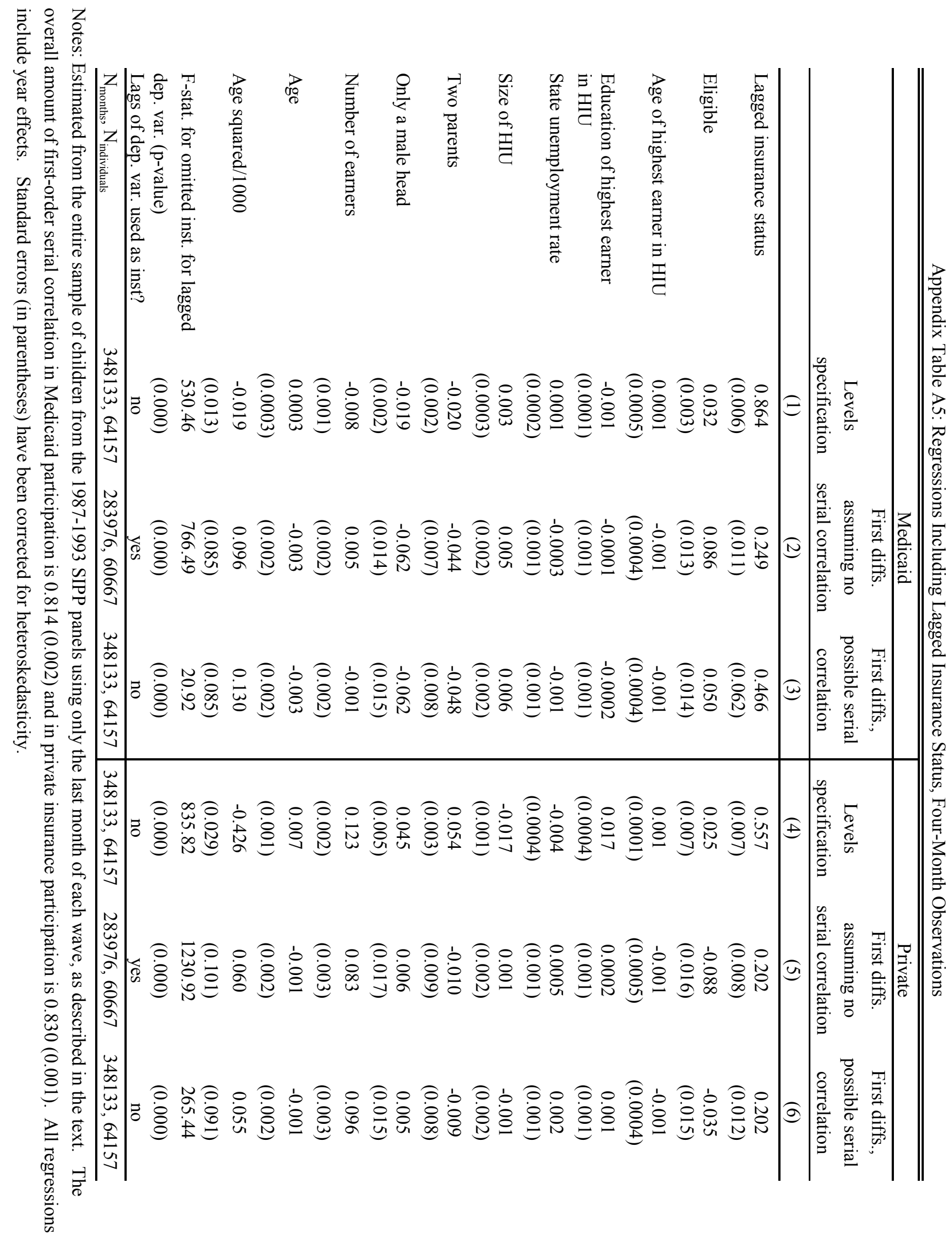




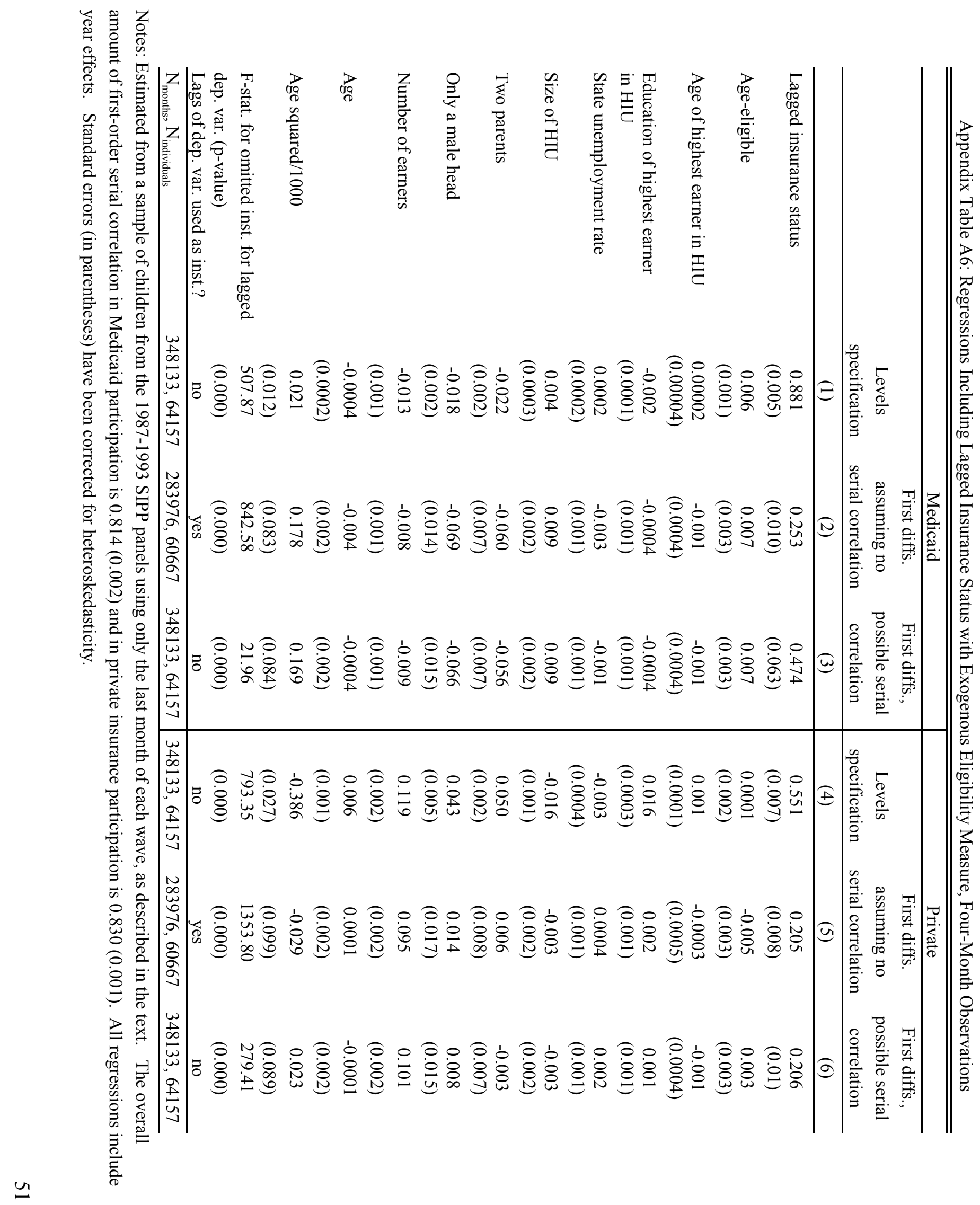

